\title{
MIASTO-KURORT KOŁOBRZEG PO PIERWSZYM ROKU PANDEMII COVID-19
}

\section{Wprowadzenie}

Pandemia COVID-19 w Polsce oficjalnie rozpoczęła się w dniu 4 marca 2020 r. z chwilą potwierdzenia pierwszego przypadku koronowirusa w Polsce u 66-letniego Mieczysława Opałki, mieszkańca niewielkiej miejscowości Cybinka w województwie lubuskim (Medonet, 2021). Już kilkanaście dni później, 13 marca 2020 r., weszło w życie rozporządzenie Ministra Zdrowia z dnia 13 marca 2020 r. w sprawie ogłoszenia na obszarze Rzeczypospolitej Polskiej stanu zagrożenia epidemicznego, wprowadzające w okresie od dnia 14 marca 2020 r. do odwołania na obszarze Rzeczypospolitej Polskiej stan zagrożenia epidemicznego w związku z zakażeniami wirusem SARS-CoV-2. W rozporządzeniu tym ustalono między innymi wstrzymanie udzielania pacjentom świadczeń opieki zdrowotnej realizowanych w ramach działalności w zakresie lecznictwa uzdrowiskowego, o którym mowa w art. 2 pkt 1 ustawy z dnia 28 lipca 2005 r. o lecznictwie uzdrowiskowym, uzdrowiskach i obszarach ochrony uzdrowiskowej oraz o gminach uzdrowiskowych (Medexpress, 2020). Ponowne otwarcie uzdrowisk nastąpiło dopiero 15 czerwca $2020 \mathrm{r}$. (Narodowy Fundusz Zdrowia, 2020a). Jednak przy niespełna 50\% obłożeniu uzdrowiska po raz kolejny zamknięto rozporządzeniem z dnia 24 października 2020 r. (Narodowy Fundusz Zdrowia, 2020b). Nieomal całkowite wygaszenie świadczenia usług lecznictwa uzdrowiskowego trwało aż do 11 marca 2021 r., kiedy to po czterech miesiącach wznowione zostało lecznictwo uzdrowiskowe (Prawo.pl, 2021). Można tym samym stwierdzić, że okres od 13 marca 2020 r. do 11 marca 2021 r. był najtrudniejszym czasem dla Kołobrzegu i polskich uzdrowisk od momentu zakończenia II wojny światowej. Od 1945 r. nie zdarzyło się by w ciągu jednego roku przez siedem miesięcy polskie lecznictwo uzdrowiskowe 
było nieomal zupełnie zamknięte. Sytuacja ta stanowi bardzo poważne zagrożenie dla dalszego funkcjonowania polskich uzdrowisk, a pewną formą przeciwdziałania temu kryzysowi była koncepcja „Narodowego Programu Wsparcia Polskich Uzdrowisk" promowana przez Stowarzyszenie Gmin Uzdrowiskowych RP (Stowarzyszenie Gmin Uzdrowiskowych RP, 2020). 20 listopada 2020 r. podczas spotkania z przedstawicielami gmin uzdrowiskowych wiceminister rozwoju, pracy i technologii Andrzej Gut-Mostowy zaproponował koncepcję utworzenia specjalnego programu wsparcia dla gmin uzdrowiskowych, pt. „Polskie Uzdrowiska ku przyszłości - zmiana funkcjonowania gmin uzdrowiskowych. Rozwój uzdrowisk w kierunku wielofunkcyjności z nowymi produktami zdrowotnymi" o szacunkowej wartości ok. 1 mld zł. Według założeń miał on za zadanie zwiększyć atrakcyjność gmin uzdrowiskowych dla kuracjuszy krajowych i zagranicznych oraz zachęcić ich do korzystania z wysokiej jakości usług zdrowotnych i rekreacyjnych na terenie tych gmin (Ministerstwo Rozwoju, Pracy i Technologii, 2020). Według stanu na dzień 30 marca 2021 r. projekt ten miał znaleźć swoje odzwierciedlenie także w Krajowym Programie Odbudowy na lata 2021-2026.

\section{Przegląd literatury i materiałów źródłowych}

Pandemia COVID-19 bardzo wyraźnie odbiła się na funkcjonowaniu miejscowości, regionów i państw o rozwiniętej funkcji turystycznej. Artykuły naukowe związane ze skutkami COVID-19 dla gospodarki turystycznej zaczęto publikować już w pierwszych miesiącach 2020 r. w państwach Azji Południowo-Wschodniej, takich jak Malezja, Singapur, Hongkong, a po upływie kolejnych dwóch-trzech miesięcy pojawiły się wyniki badań w Polsce (Wiskulski, 2020) i innych krajach europejskich. Na początku pandemii publikacje dotyczyły najczęściej stanu gospodarki i przemysłu turystycznego poszczególnych krajów: Malezji (Lee-Peng, Mui-Yin, Kim-Leng, Kit-Leng, 2020) czy Hiszpanii (Moreno-Luna, Robina-Ramírez, Sánchez, Castro-Serrano, 2021), artykuły poświęcone były funkcjonowaniu sektora turystycznego po wprowadzeniu ograniczeń w działaniu przemysłu turystycznego. Szybki rozwój epidemii skutkował z kolei pojawieniem się prac wskazujących kierunki badań oraz opisujących stosowane w nich metody badawcze, czego interesującym przykładem może być praca Davahli, Karwowski, Sonmez, Apostolopoulos (2020). Nieco inne spojrzenie prezentują opracowania nawiązujące do następstw pojawiania się wcześniejszych wirusów i zagrożeń epidemicznych, czego 
efektem były z kolei projekcje skutków ekonomicznych dla regionów turystycznych świata oraz propozycje przeciwdziałania ponoszonym stratom ekonomicznym (Skare, Soriano, Porada-Rochoń, 2021). Po upływie roku trwania stanu pandemii w skali całego świata pojawiły się pierwsze opracowania zbiorcze, ukazujące następstwa pandemii, kierunki podejmowanych działań oraz sytuację społeczno-gospodarczą państw świata (np. OECD, 2021; Rathore, Dwivedi, 2021). Pojawiły się także prace, których autorzy podejmowali próby szacowania skali spadku ruchu turystycznego na bazie wcześniejszych zdarzeń (kryzysy, epidemie), a także z zastosowaniem metod modelowania matematycznego (Fotiadis, Polyzos, Huan, 2020). Należy również wspomnieć o pracach badawczych, których autorzy podjęli się badań skutków społeczno-ekonomicznych COVID-19, np. COVID-19 jako inhibitor aktywności turystycznej o czym świadcza wakacyjne plany Polaków (Kowalska, Niezgoda, 2020), a także wykorzystywania mediów w badaniach nastrojów i zachowania się konsumentów usług turystycznych (Flores-Ruiz, Elizondo-Salto, Barroso-González, 2021) czy skutków pandemii dla Krakowa (Walas, Kruczek, 2020). Praca ta reprezentuje przekrojowe opracowania wyników badań miejskich obszarów turystycznych. Niniejszy artykuł opiera się na badaniach podstawowych (opłata uzdrowiskowa, rynek nieruchomości) oraz danych Urzędu Miasta Kołobrzeg (2020), Głównego Urzędu Statystycznego (GUS) (2020), Urzędu Statystycznego w Szczecinie (2021) i Wojewódzkiego Urzędu Pracy w Szczecinie (2021).

\section{Cele i metodyka badań}

Sytuacja związana z pandemią COVID-19 nie ma jakiegokolwiek wcześniejszego odpowiednika w przypadku polskich uzdrowisk i miejscowości, na terenie których świadczone są usługi lecznictwa uzdrowiskowego. Celem prowadzonych w 2020 i 2021 r. badań było zatem podjęcie próby ustalenia, jaki wpływ na funkcjonowanie uzdrowiska Kołobrzeg miała pandemia COVID-19 w aspekcie cyklicznego zamykania i otwierania obiektów lecznictwa uzdrowiskowego w miejscowości uzdrowiskowej - miejscu atrakcyjnym dla potencjalnych mieszkańców i inwestorów.

Spośród wszystkich polskich obszarów uzdrowiskowych Kołobrzeg i jego zaplecze jest obszarem największej w skali kraju koncentracji turystycznej bazy noclegowej, która według danych GUS za 2020 r. liczyła 33077 miejsc noclegowych (dla porównania Warszawa - 31769 miejsc noclegowych, Kraków - 28153 miejsc noclegowych) (Bank Danych Lokalnych, 2021). W powiecie kołobrzeskim w 2020 r. przebywało 559 tys. turystów 
(szóste miejsce w skali kraju, spadek o 34\%), jednak udzielono w nim aż 3 137,2 tys. osobonoclegów (pierwsze miejsce w skali kraju) przy stopniu wykorzystania bazy noclegowej na poziomie 43,8\% (Główny Urząd Statystyczny, 2021). Tak szeroko liczony obszar miejski Kołobrzegu pokrywa się z granicami trzech nadmorskich gmin powiatu kołobrzeskiego, tworzących tzw. Miejski Obszar Funkcjonalny Kołobrzeg.

Prowadzone badania i obserwacje skupiły się na czterech kluczowych zagadnieniach, takich jak:

1. Zmiany wpływów bezpośrednich w budżecie miasta z tytułu opłaty uzdrowiskowej.

2. Straty finansowe miasta uzdrowiskowego z tytułu zawieszania funkcjonowania obiektów turystycznych i lecznictwa uzdrowiskowego, a także innych podmiotów gospodarczych.

3. Sytuacja na rynku pracy po pierwszym roku stanu zagrożenia pandemią COVID-19.

4. Zmiany wielkości i rodzajów realizowanych inwestycji mieszkaniowych, apartamentowych, hotelowych w okresie trwania pandemii COVID-19. Należy przy tym podkreślić, że w przypadku pkt. 1 i 2 mamy do czynienia ze skutkami bezpośrednimi, następującymi z miesiąca na miesiąc i kumulującymi zaległości finansowe, natomiast w przypadku rynku pracy odczuwane są głównie skutki pośrednie. Z kolei w przypadku procesów inwestycyjnych na rynku nieruchomości można dostrzec, że starły się tu "obawy i nadzieje" związane z inwestowaniem na rynku nieruchomości. Są to z jednej strony obawy, że wartość środków finansowych podczas kryzysu dramatycznie spadnie, a zatem trzeba je odpowiednio zainwestować, a z drugiej strony kluczowy był tu wybór miejsca przeznaczenia tych środków finansowych. Kołobrzeg w 2019 r. (przed pandemią) osiągnął najwyższą w swojej historii skalę odnotowywanego ruchu turystycznego (liczba osobonoclegów i liczba turystów), a także liczbę oddawanych do użytku lokali mieszkalnych. Był to także według danych GUS jeden ze znaczących mniejszych rynków nieruchomości niemieszkalnych i mieszkaniowych w skali kraju. Warto podkreślić, że mimo pewnych zagrożeń (np. niewydolny układ komunikacyjny) w Kołobrzegu osiągnięto najwyższe w historii wpływy z opłaty uzdrowiskowej w skali kraju i rekordowe przyrosty nowych zasobów lokalowych (Główny Urząd Statystyczny, 2020). Skłania to do podjęcia próby zbadania, jak największy kurort w kraju, będący u szczytu swojego rozwoju, funkcjonuje w warunkach zagrożenia epidemicznego - z uwzględnieniem bardzo dotkliwych okresów ograniczania, a nawet zupełnego zamknięcia wielu turystycznych i leczniczych obiektów noclegowych i innych działalności gospodarczych. 


\section{Wpływy z opłaty uzdrowiskowej, sytuacja finansowa miasta i zmiany wielkości bezrobocia}

Podejmowanie badań skali i stopnia rozwoju danego obszaru turystycznego jest niezwykle trudnym przedsięwzięciem ze względu na nieomal zupełny brak oficjalnych danych statystycznych, raportów, analiz itp. na poziomie lokalnym. W Kołobrzegu jednak od siedmiu lat, za sprawą trafnie podjętych decyzji o zarządzaniu wpływami do budżetu miasta, gromadzone są comiesięczne bardzo dokładne dane pośrednie, dotyczące kwot wpływów z opłaty uzdrowiskowej. Środki te są pozyskiwane zgodnie z zapisami Ustawy z dnia 28 lipca 2005 r. o lecznictwie uzdrowiskowym, uzdrowiskach i obszarach ochrony uzdrowiskowej oraz gminach uzdrowiskowych, według art. 48 „Gmina uzdrowiskowa w celu realizacji zadań, o których mowa w art. 46, ma prawo do pobierania opłaty uzdrowiskowej na zasadach określonych w przepisach odrębnych" (Ustawa, 2020). Natomiast zgodnie $\mathrm{z}$ art. 49.1

Gmina uzdrowiskowa realizująca zadania, o których mowa w art. 46, otrzymuje dotację $\mathrm{z}$ budżetu państwa $\mathrm{w}$ wysokości równej wpływom $\mathrm{z}$ tytułu opłaty uzdrowiskowej pobranej w uzdrowisku w roku poprzedzającym rok bazowy w rozumieniu ustawy z dnia 13 listopada 2003 r. o dochodach jednostek samorządu terytorialnego (Dz. U. z 2020 r. poz. 23, 374 i 1086) (Ustawa, 2020).

Z kolei zgodnie z art. 49.2 „Minister właściwy do spraw finansów publicznych, po zasięgnięciu opinii reprezentacji jednostek samorządu terytorialnego, określi, w drodze rozporządzenia, tryb i terminy ustalenia oraz przekazania dotacji, kierując się potrzebą zabezpieczenia środków na realizację zadań gmin uzdrowiskowych" (Ustawa, 2020). Środki z opłaty uzdrowiskowej stanowią zatem bardzo istotną część wpływów większości polskich uzdrowisk (np. Kołobrzeg, Świnoujście, Krynica itp.). Na tym tle absolutnie wyjątkowa sytuacja ma miejsce w Kołobrzegu, który do 2020 r. uzyskiwał najwyższą w skali kraju kwotę z tytułu pobieranej opłaty uzdrowiskowej (tab. 1).

W latach 2016-2019 systematycznie rosła kwota środków finansowych pozyskiwanych co miesiąc z opłaty uzdrowiskowej do budżetu Gminy Miasto Kołobrzeg. Przykładowo kwota za 2019 r. wynosząca 16,2 mln zł była zwiększona o dotację uzdrowiskową w wysokości około 15,0 mln zł, co oznacza, że tylko z tytułu opłat uzdrowiskowych i dotacji Gmina Miasto Kołobrzeg uzyskiwała środki w wysokości ponad 31,2 mln zł, co przy dochodach 268,88 mln zł stanowiło aż $11,6 \%$ dochodów miasta (2019 r. zakończony nadwyżką budżetową w wysokości 16,1 mln zł) 


\begin{tabular}{|c|c|c|c|c|c|c|c|c|c|c|c|c|c|}
\hline$\alpha^{\circ}$ & $\underline{N}$ & $F$ & 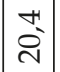 & 1 & 1 & 1 & 1 & 1 & 1 & 1 & 1 & 1 & $\begin{array}{l}0 \\
0 \\
i\end{array}$ \\
\hline 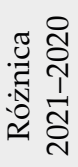 & $\begin{array}{l}-\infty \\
\infty \\
10 \\
2 \\
0 \\
1\end{array}$ & 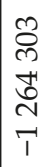 & 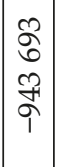 & 1 & 1 & 1 & 1 & 1 & 1 & 1 & 1 & 1 & 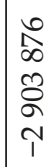 \\
\hline$\partial^{\circ}$ & $\underset{1}{10}$ & 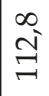 & $\begin{array}{l}\mathcal{N} \\
\widetilde{N} \\
\end{array}$ & $\begin{array}{l}0 \\
0 \\
0\end{array}$ & $\stackrel{0}{+}$ & à & \begin{tabular}{|l|} 
L \\
L
\end{tabular} & $\begin{array}{l}-\overrightarrow{1} \\
\infty \\
\infty\end{array}$ & 突 & $\frac{N}{\sigma}$ & à & $\begin{array}{l}0 \\
15\end{array}$ & ثิ \\
\hline 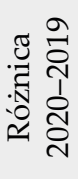 & $\begin{array}{l}\tilde{N} \\
m \\
m \\
m\end{array}$ & 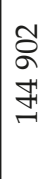 & 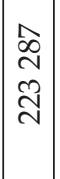 & $\begin{array}{l}+ \\
F \\
+ \\
\infty \\
10 \\
\infty \\
1\end{array}$ & \begin{tabular}{|c|}
0 \\
10 \\
$\infty$ \\
0 \\
0 \\
+1 \\
+1 \\
7
\end{tabular} & 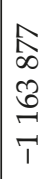 & $\begin{array}{l}10 \\
\tilde{n} \\
10 \\
0 \\
尺 \\
\uparrow\end{array}$ & $\begin{array}{l}\stackrel{\Upsilon}{N} \\
\text { సે } \\
\text { సิ }\end{array}$ & 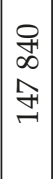 & 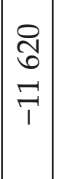 & 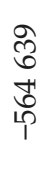 & 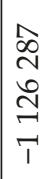 & 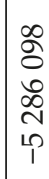 \\
\hline 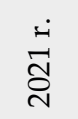 & $\begin{array}{l}\hat{0} \\
\infty \\
\text { 命 }\end{array}$ & $\begin{array}{l}2 \\
\hat{m} \\
+1 \\
+1\end{array}$ & 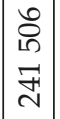 & 1 & 1 & 1 & 1 & 1 & 1 & 1 & 1 & 1 & $\begin{array}{l}\infty \\
\infty \\
\sim \\
\text { N } \\
\text { ம }\end{array}$ \\
\hline 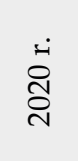 & $\begin{array}{l}N \\
0 \\
\infty \\
N \\
N\end{array}$ & $\begin{array}{l}\mathfrak{N} \\
0 \\
\infty \\
\infty \\
\hat{N} \\
-1\end{array}$ & 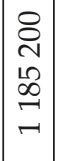 & 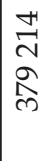 & 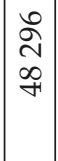 & 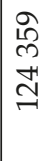 & 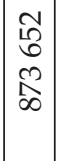 & $\begin{array}{l}\mathbb{Z} \\
\sim \\
2 \\
2 \\
\sigma \\
-\end{array}$ & 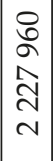 & 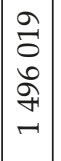 & $\begin{array}{l}8 \\
\infty \\
\infty \\
\infty\end{array}$ & 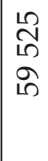 & $\begin{array}{l}\infty \\
0 \\
0 \\
\infty \\
\sigma \\
0 \\
0\end{array}$ \\
\hline 宛 & 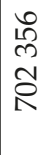 & $\begin{array}{l}0 \\
\infty \\
\infty \\
m \\
m \\
\sim \\
-1\end{array}$ & $\begin{array}{l}\sim \\
\sigma \\
\sigma \\
\sigma \\
\sigma\end{array}$ & 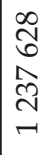 & 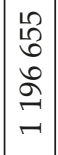 & $\begin{array}{l}0 \\
\infty \\
N \\
\infty \\
\infty \\
\sim \\
-1\end{array}$ & $\begin{array}{l}0 \\
\infty \\
- \\
+ \\
0 \\
8 \\
-1\end{array}$ & 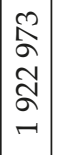 & 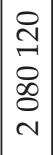 & $\begin{array}{l}\infty \\
0 \\
0 \\
1 \\
0 \\
10 \\
-1\end{array}$ & \begin{tabular}{l}
$\infty$ \\
\multirow{+}{*}{} \\
$m$ \\
$\infty$ \\
$\infty$ \\
-1
\end{tabular} & $\begin{array}{l}\mathcal{N} \\
\infty \\
10 \\
\infty \\
\\
-\end{array}$ & 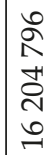 \\
\hline $\begin{array}{l}\dot{\Delta} \\
\stackrel{\infty}{\sigma} \\
\stackrel{\sim}{\sigma}\end{array}$ & 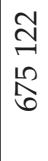 & $\begin{array}{l}\infty \\
0 \\
\infty \\
\infty \\
\infty \\
\\
-1 \\
-1\end{array}$ & $\begin{array}{l}\mathscr{m} \\
\stackrel{9}{F} \\
\vec{F} \\
\dot{0} \\
-\end{array}$ & $\begin{array}{l}0 \\
8 \\
10 \\
1 \\
-1 \\
-1\end{array}$ & $\begin{array}{c}\infty \\
\infty \\
\infty \\
\mathscr{0} \\
\infty \\
0 \\
-1\end{array}$ & 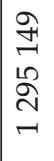 & 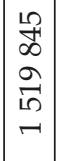 & $\begin{array}{l}\infty \\
2 \\
2 \\
8 \\
2 \\
-1\end{array}$ & 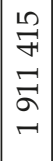 & $\begin{array}{l}0 \\
0 \\
0 \\
\llcorner \\
0 \\
\not \\
\not \\
-1\end{array}$ & 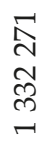 & 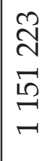 & 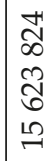 \\
\hline$\stackrel{\dot{\sim}}{\stackrel{\sim}{\circ}}$ & 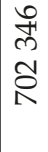 & $\begin{array}{l}\text { 영 } \\
\text { ơ } \\
\text { ó }\end{array}$ & 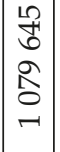 & $\begin{array}{l}\sigma \\
\text { - } \\
\hat{2} \\
0 \\
0 \\
-1\end{array}$ & 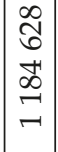 & 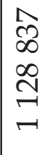 & $\begin{array}{l}2 \\
\hat{N} \\
2 \\
2 \\
10 \\
-1\end{array}$ & $\begin{array}{l}\vec{Z} \\
F \\
\vec{\infty} \\
-\end{array}$ & $\begin{array}{l}0 \\
\infty \\
\infty \\
m \\
\stackrel{1}{1} \\
-1\end{array}$ & \begin{tabular}{l}
$\mathfrak{N}$ \\
$\mathfrak{2}$ \\
$\infty$ \\
\multirow{+}{+}{} \\
-
\end{tabular} & 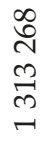 & 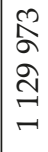 & 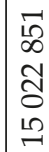 \\
\hline $\begin{array}{l}\dot{1} \\
\stackrel{0}{\circ} \\
\stackrel{\sim}{\sim}\end{array}$ & $\begin{array}{l}\text { \& } \\
\stackrel{+}{+} \\
\text { क्ष }\end{array}$ & $\begin{array}{l}\infty \\
2 \\
+1 \\
10 \\
2\end{array}$ & 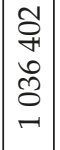 & $\begin{array}{l}N \\
\hat{N} \\
\infty \\
0 \\
0 \\
-1\end{array}$ & 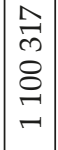 & $\begin{array}{l}\infty \\
\infty \\
\infty \\
\infty \\
\infty \\
-1 \\
-1\end{array}$ & 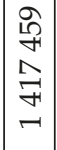 & $\begin{array}{l}\alpha \\
\delta \\
\tilde{\sigma} \\
\infty \\
-1\end{array}$ & 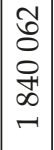 & 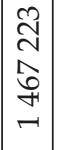 & $\begin{array}{l}8 \\
\infty \\
0 \\
尺 \\
\text { ஸे } \\
-1\end{array}$ & 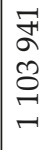 & 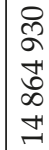 \\
\hline 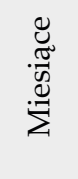 & - & $\Xi$ & 目 & Z & $>$ & 5 & $\stackrel{\ominus}{>}$ & $\stackrel{\Xi}{>}$ & 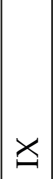 & $\times$ & $\bar{x}$ & $\bar{\nabla}$ & 沀 \\
\hline
\end{tabular}


(Raport, 2019). W 2020 r. za sprawą ograniczeń funkcjonowania obiektów turystyczno-uzdrowiskowych dochód miasta z tytułu wpływów z opłaty uzdrowiskowej spadł do $10,9 \mathrm{mln}$ zł, czyli do poziomu $67,38 \%$ wpływów z 2019 r. Trzy pierwsze miesiące w 2021 r. to z kolei wpływy z tytułu opłaty uzdrowiskowej na poziomie zaledwie 2,69\%. W porównaniu do lat wcześniejszych wyniki za 2020 r. były bardzo słabe, a rezultaty z początku $2021 \mathrm{r}$. katastrofalne. Oznacza to także istotne problemy w bieżącym funkcjonowaniu miasta, zwłaszcza w zakresie zaspokajania potrzeb mieszkańców i inwestycji. Należy przy tym podkreślić, że w ciągu ostatniego roku trwania pandemii COVID-19 odnotowano aż cztery miesiące, gdy wpływy z opłaty uzdrowiskowej nie przekraczały $10 \%$ wpływów miesięcznych z lat wcześniejszych, a w trzech miesiącach (maj, grudzień 2020 r., styczeń 2021 r.) wpływy z tego tytułu wynosiły około 4-5\%. To miesiące, w których większość sektora turystyczno-uzdrowiskowego Kołobrzegu przestała funkcjonować, a bezpośrednim tego potwierdzeniem był nieomal zupełny brak poboru opłaty uzdrowiskowej.

Charakterystyczną cechą powiatu kołobrzeskiego w latach 2004-2019 był systematyczny spadek poziomu bezrobocia z wartości rzędu $14 \%$ do zaledwie 1,2\% w listopadzie 2019 r. (rys. 1).

Zmiany $\mathrm{w}$ poziomie bezrobocia co roku były w znacznym stopniu podporządkowane sezonowości ruchu turystycznego, przy czym ciąły rozwój funkcji miasta przyczyniał się do systematycznego corocznego

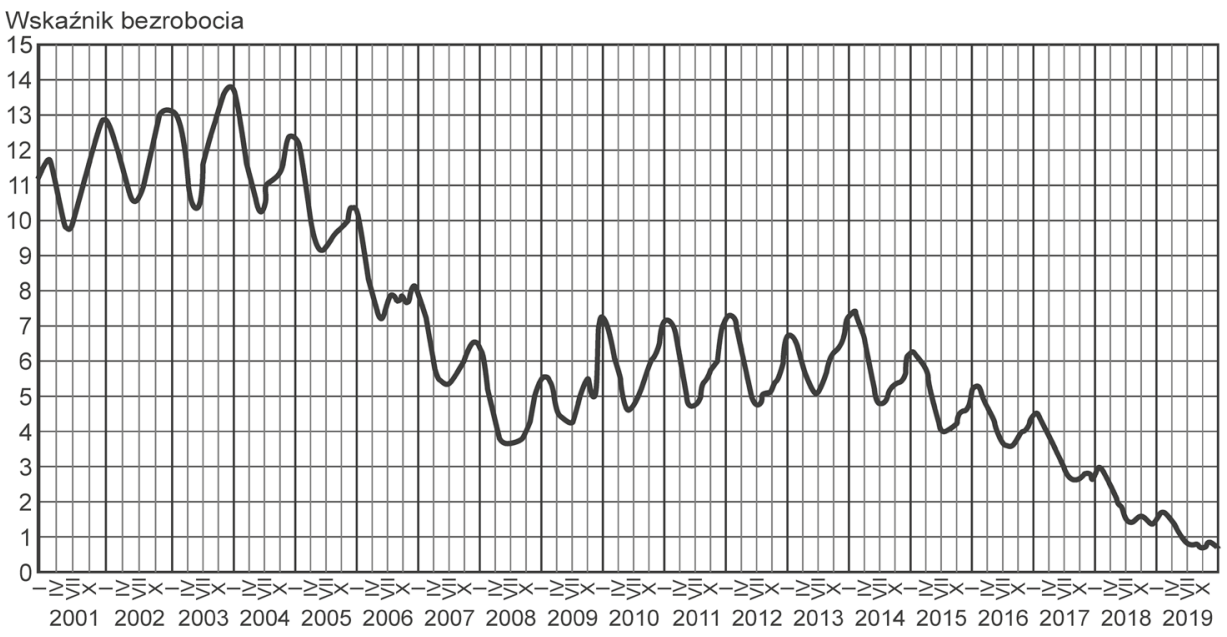

Rysunek 1. Dynamika wskaźnika bezrobocia w Kołobrzegu w latach 2001-2019 Źródło: Raport o stanie Gminy Miasto Kołobrzeg za rok 2019 (2019) 
zmniejszania poziomu bezrobocia. Ogłoszenie stanu zagrożenia pandemicznego COVID-19 w marcu 2020 r. zupełnie zmieniło dotychczasowy cykl comiesięcznych zmian wielkości odnotowywanego poziomu bezrobocia. Pierwszy raz od bardzo wielu lat w miesiącach marzec-maj doszło do załamania na rynku pracy i bardzo znaczącego wzrostu poziomu bezrobocia $\mathrm{w}$ porównaniu $\mathrm{z}$ okresem przed pandemią.

Gospodarka turystyczna i powiązana z nią gospodarka uzdrowiskowa są sektorami dość wrażliwymi na sytuację społeczno-gospodarczą i ograniczenia ruchu turystycznego. W marcu 2020 r. za sprawą zamknięcia granic, a także ograniczenia funkcjonowania obiektów lecznictwa uzdrowiskowego, hoteli i znacznej części pozostałej bazy noclegowej miasta doszło do bardzo silnego załamania wielkości ruchu turystycznego. Po ogłoszeniu zamknięcia sektora turystycznego znaczna część podmiotów gospodarczych zaczęła ograniczać działalność i redukować koszty poprzez zwalnianie osób zatrudnionych w ramach umów okresowych i pracy tymczasowej. Wygaszono także nabory na wolne stanowiska pracy. Przed wybuchem pandemii w powiecie kołobrzeskim notowano bardzo niskie bezrobocie. W okresie zimowo-wiosennym (luty 2020 r.) bez zatrudnienia było tylko 459 osób, a stopa bezrobocia w powiecie wynosiła niespełna 1,5\%. Oznaczało to praktyczny brak występowania zjawiska bezrobocia w styczniu-lutym $2020 \mathrm{r}$. (rys. 2, 3).

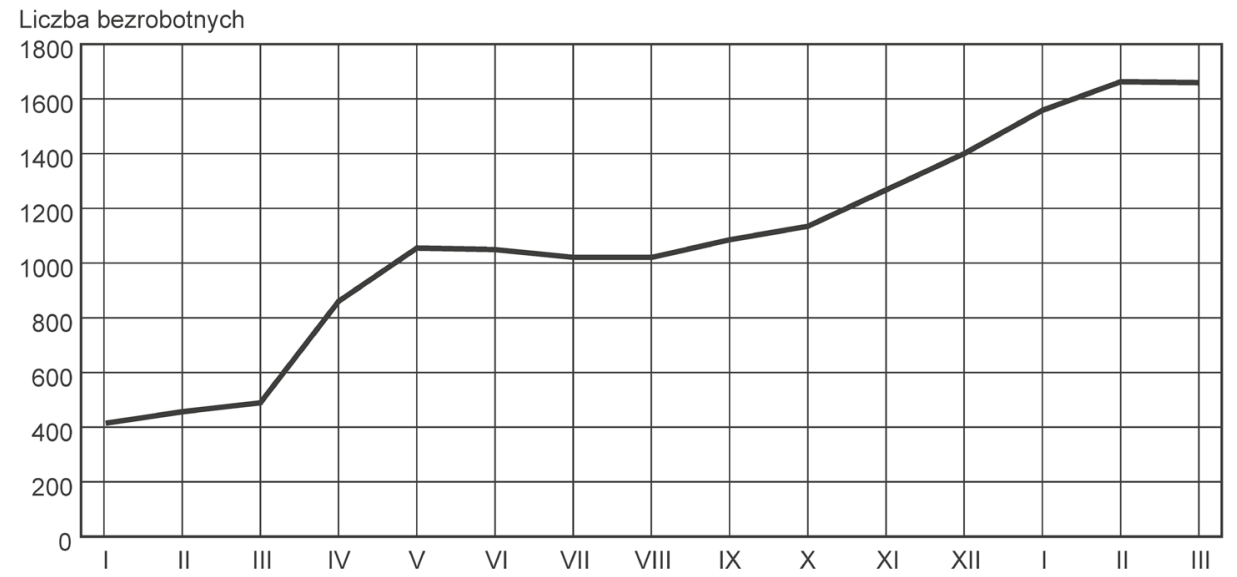

Rysunek 2. Liczba osób bezrobotnych w powiecie kołobrzeskim według miesięcy w latach 2020-2021

Źródło: opracowanie własne na podstawie danych pozyskanych z Wojewódzkiego Urzędu Pracy w Szczecinie (2021) 


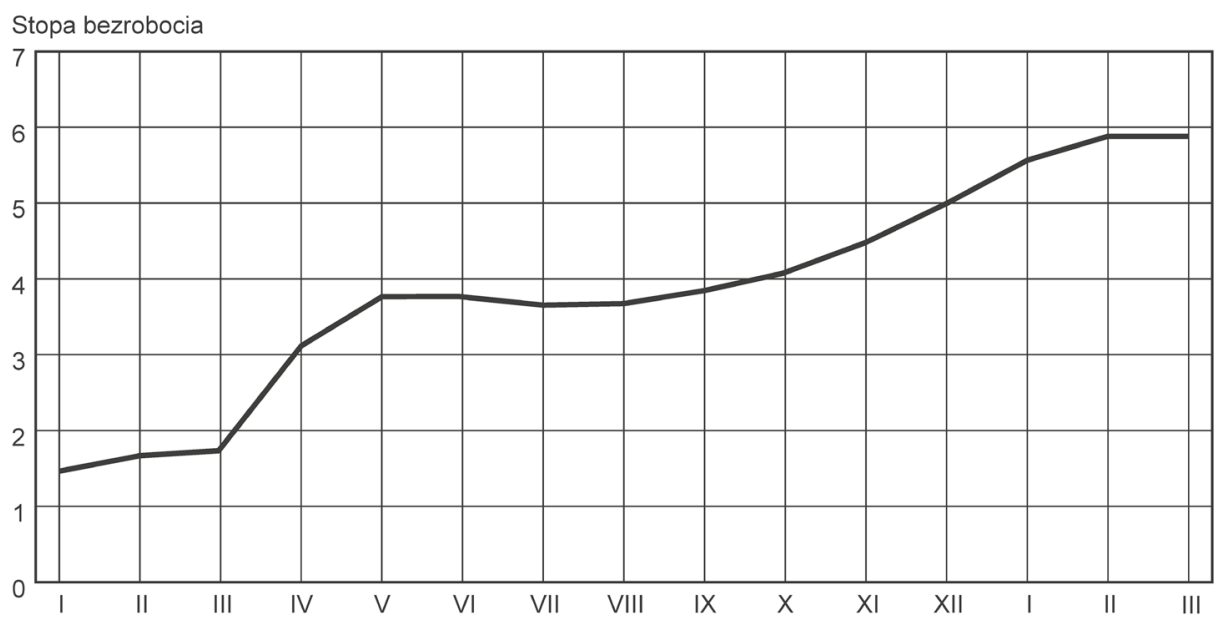

Rysunek 3. Wysokość stopy bezrobocia w powiecie kołobrzeskim według miesięcy w latach 2020-2021

Źródło: opracowanie własne na podstawie danych pozyskanych z Wojewódzkiego Urzędu Pracy w Szczecinie (2021)

W ciągu zaledwie dwóch miesięcy poziom bezrobocia podwoił się, osiągając liczbę nieco ponad 1000 osób bez zatrudnienia przed rozpoczęciem sezonu letniego. Było to najsilniejsze jednorazowe załamanie rynku pracy, odnotowane podczas ostatniego roku. Niestety utrzymujące się problemy $\mathrm{w}$ funkcjonowaniu sektora turystycznego, a także kolejne posezonowe zamknięcie funkcji turystyczno-uzdrowiskowych spowodowały dalszy wzrost poziomu bezrobocia. W ciągu następnych sześciu miesięcy bezrobocie wzrosło o kolejne $50 \%$, a liczba osób bezrobotnych w lutym i marcu 2021 r. osiągnęła po 1664 i 1667 osób przy stopie bezrobocia wynoszącej $5,9 \%$ (rys. 2,3). Należy przy tym podkreślić, że wzrost ten byłby o wiele większy, jednak bardzo istotną rolę odegrała decyzja o ryczałtowym finansowaniu funkcjonowania 23 szpitali i sanatoriów uzdrowiskowych. To pozwoliło zachować kilka tysięcy miejsc pracy. Największe zwolnienia miały miejsce w kilku (2-3) spośród ponad 100 dużych i średnich obiektów hotelowo-apartamentowych, których właściciele prawdopodobnie wcześniej mieli pewne trudności z płynnością finansową. Odcięcie od bieżących płatności i ograniczenia funkcjonowania małych firm wpłynęły na dodatkową redukcję liczby miejsc pracy, a to z kolei przyczyniło się do znaczącego wzrostu bezrobocia w powiecie kołobrzeskim od marca 2020 r. do lutego 2021 r. Sytuacja zaczęła się stabilizować od lutego $2021 \mathrm{r}$. 


\section{Rynek budowlany (inwestycje mieszkaniowe, apartamentowe, hotelowe)}

Miasto Kołobrzeg od wielu lat jest obszarem o dość szybko rosnących zasobach mieszkań i apartamentów, a także pokoi hotelowych. Interesujące było zatem ustalenie, jak zachowywał się rynek mieszkaniowy, apartamentowy i hotelowy w pierwszym roku stanu zagrożenia pandemią COVID-19. Realizowane inwestycje związane z miejscami noclegowymi można podzielić na: hotelowe, hotelowo-apartamentowe, apartamentowe i mieszkaniowe. W 2019 r. w powiecie kołobrzeskim oddano do użytku łącznie 1069 mieszkań (w tym 847 w Kołobrzegu), natomiast w 2020 r. było to jedynie 906 mieszkań. Całkowite zasoby mieszkaniowe w Kołobrzegu w 2019 r. liczyły 24530 nieruchomości, natomiast w 2020 r. przekroczyły 25000 lokali mieszkalnych. Już w 2019 r. Kołobrzeg zajmował pierwsze miejsce w kraju pod względem liczby mieszkań (549) na 1000 mieszkańców (Rynek pierwotny, 2020). Oddanie do użytku w 2020 r. kolejnych kilkuset lokali mieszkalnych pozwoliło z pewnością umocnić się miastu na pozycji lidera w skali całego kraju. Na podstawie raportu PKOBP za pierwszy kwartał 2021 r. (PKO Bank Polski, 2021) i zawartych w nim danych za 2020 r. (stan na dzień 4.03.2021 r.) można stwierdzić, że stan zagrożenia pandemicznego COVID-19 odbił się w istotny sposób na rynku nieruchomości Kołobrzegu. Wbrew prognozom rynek nieruchomości w powiecie kołobrzeskim zareagował najwyższym przyrostem cen domów mieszkalnych w województwie zachodniopomorskim (rys. 4), odnotowując wzrost o 1527 zł/m². Można zakładać, że taka reakcja rynku wynikała z jednej strony z obaw o sytuację społeczno-gospodarczą i otoczenie makroekonomiczne, a z drugiej strony osoby fizyczne i prawne poszukiwały możliwości bezpiecznego ulokowania kapitału. Miasto Kołobrzeg razem z otaczającym go miejskim obszarem funkcjonalnym (teren powiatu kołobrzeskiego) od wielu lat jest bardzo atrakcyjnym obszarem lokalizacji inwestycji hotelowych, apartamentowych i mieszkaniowych. Kołobrzeg jako największe nadmorskie polskie miasto zachodniej części wybrzeża, mające status największego polskiego uzdrowiska, utrzymał dość stabilne funkcjonowanie gospodarki, a wzrost poziomu bezrobocia w okresie pandemii COVID-19 okazał się nie bardzo dokuczliwy i w lutym 2021 r. mieścił się w granicach tzw. bezrobocia naturalnego (wzrost z 1,4\% na 6\%). Inwestorzy zauważyli przy tym znaczącą poprawę dostępności komunikacyjnej miasta (drogi ekspresowe S-6 i S-11), realny brak oznak głębokiego kryzysu (np. brak pustostanów na rynku lokali usługowych) i docenili szeroko rozumiany potencjał społeczno-gospodarczy i rozwojowy miasta. Co ciekawe w latach 
2020-2021 znaczący wzrost cen odnotowany został także w sąsiednim Koszalinie, do którego dojazd drogą ekspresową z Kołobrzegu trwa niespełna 30 minut. Dotychczasowy całoroczny charakter funkcjonowania sektora turystycznego Kołobrzegu i jego wypracowany potencjał rozwojowy były prawdopodobnie przyczyną wzrostu, a nie załamania cen odnotowywanych na rynku nieruchomości (rys. 4).

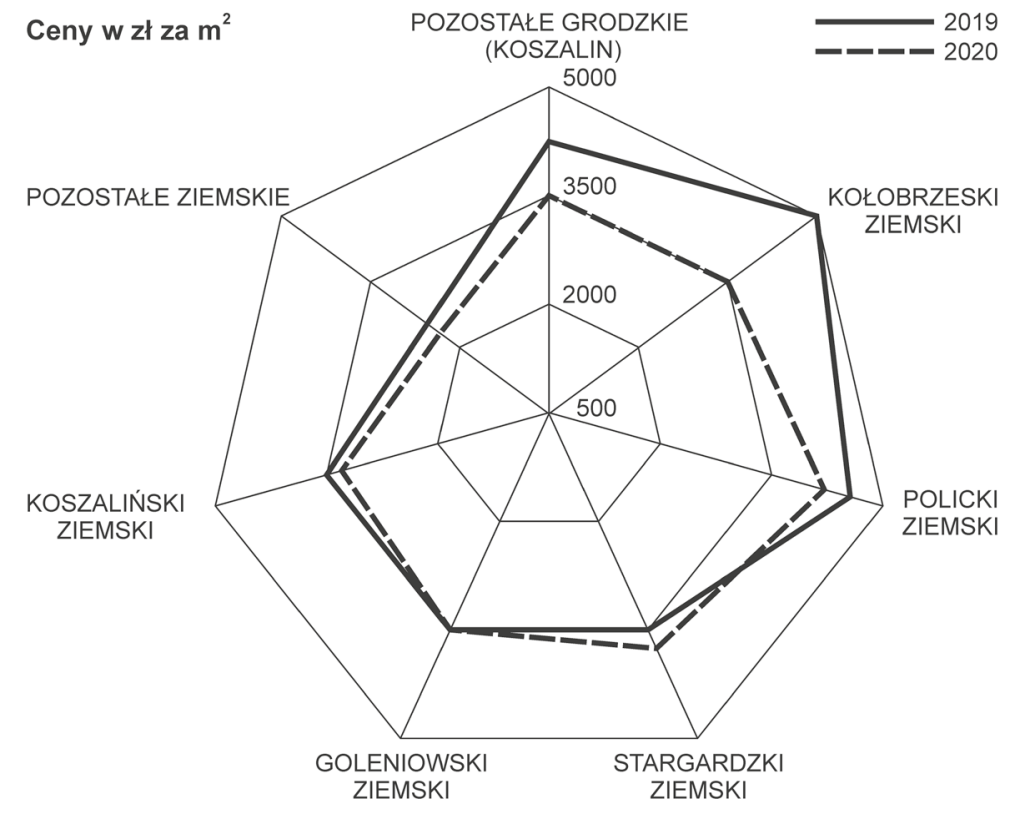

Rysunek 4. Ceny transakcyjne domów według powiatów

Źródło: opracowanie na podstawie PKO Bank Polski (2021, s. 56)

Należy przy tym zaznaczyć, że miasto Kołobrzeg od wielu lat jest jednym ze znaczących rynków transakcyjnych rynku nieruchomości w skali kraju. Według ostatnich dostępnych danych z 2017 r. powiat kołobrzeski pod względem wartości transakcji na rynku lokali niemieszkalnych zajmował dziewiąte miejsce w kraju. Powiat kołobrzeski jest także wskazywany w raportach jako obszar lokalizacji nieruchomości luksusowych w zakresie luksusowych hoteli i SPA (4 obiekty tego typu) (Rynek dóbr luksusowych w Polsce, 2021). Najwięcej tego typu obiektów w lipcu 2020 r. znajdowało się w Warszawie (15), Krakowie (12), Wrocławiu (7), Sopocie (5), Kołobrzegu (4), Gdańsku (4), Zakopanem (4) i Poznaniu (3), co potwierdza, że Kołobrzeg staje się jedną z kilku popularnych lokalizacji dla inwestowania na rynku nieruchomości i wypoczynku osób dobrze zarabiających miesięcznie (7 $100 \mathrm{zł}$ brutto/mies.), zamożnych (20 000 zł 
brutto/mies.), bogatych (50 $000 \mathrm{zł} \mathrm{brutto/mies.)} \mathrm{i} \mathrm{bardzo} \mathrm{bogatych} \mathrm{(pow.}$ $1 \mathrm{mln}$ zł brutto rocznie). Sytuacja ta spowodowała, że w budowie lub projektowaniu (stan na marzec 2021 r.) były kolejne trzy obiekty luksusowe (Intercontinental, MovenPick, Woźniak) (tab. 2, 3).

Na terenie miasta Kołobrzeg w marcu 2021 r. w budowie było 11 hoteli i aparthoteli (tab. 2) oraz 25 inwestycji mieszkaniowych i apartamentowych (tab. 3). $\mathrm{Z}$ tej liczby budowę 5 hoteli i 8 inwestycji mieszkaniowych i apartamentowych rozpoczęto od marca 2020 r. - już po wybuchu pandemii COVID-19. Można stwierdzić, że pandemia nie powstrzymała zatem budowy ok. 1000 pokoi hotelowych i ok. 1300 mieszkań i apartamentów. Łącznie, według stanu na marzec 2021 r., w budowie znajdowało się 1209 pokoi hotelowych i 841 apartamentów hotelowych na ponad 5300 miejsc. Rok po wybuchu pandemii, w marcu 2021 r., na terenie miasta w budowie było również 2756 mieszkań i 1417 apartamentów przeznaczonych dla ok. 12500 osób. W sumie w ciągu najbliższych 2-3 lat (do końca 2023 r.) pojemność turystyczna i mieszkaniowa bazy noclegowej miasta może zwiększyć się w sumie o ok. 18000 miejsc noclegowych. W marcu 2021 r., obok budowanej już bazy noclegowej, na etapie przygotowanych do realizacji projektów było ponad 5100 miejsc noclegowych w obiektach hotelowych i apartamentowo-hotelowych. Z kolei przygotowane do realizacji inwestycje mieszkaniowe i apartamentowe są przeznaczone dla kolejnych 8200 osób. W sumie (według stanu na marzec 2021 r.) pojemność całej budowanej, przygotowanej i planowanej bazy noclegowej i mieszkaniowej sięga 50000 osób. Tak duża skala realizowanych w najbliższych kilku latach inwestycji wiąże się z nieomal pełnym wykorzystaniem wszystkich dostępnych terenów inwestycyjnych w obecnych granicach miasta Kołobrzeg, a łączna docelowa liczba mieszkań i apartamentów zwiększy się tym samym w ciągu najbliższych 5-7 lat z 25000 do ok. 40000. Analizy wskazuja, że w obecnych granicach administracyjnych możliwa jest realizacja tak dużej bazy noclegowej i mieszkaniowej, ale pod warunkiem bardzo znaczącej przebudowy struktury funkcjonalnej miasta oraz systemu komunikacyjnego przy bezwzględnej ochronie i uporządkowaniu wszystkich dostępnych terenów zielonych objętych ochroną. Postulowany obecnie rozwój funkcji portowych, skoncentrowanych wokół sektora offshore związanego z budową, obsługą i serwisem morskich elektrowni wiatrowych, ma umożliwić pozyskanie istotnego potencjału nieuciążliwych usług przemysłowych. Byłoby to korzystne dla lokalnego rynku pracy i zapewniłoby poprawę warunków funkcjonowania miasta Kołobrzeg. 


\begin{tabular}{|c|c|c|c|c|c|c|c|c|c|c|}
\hline 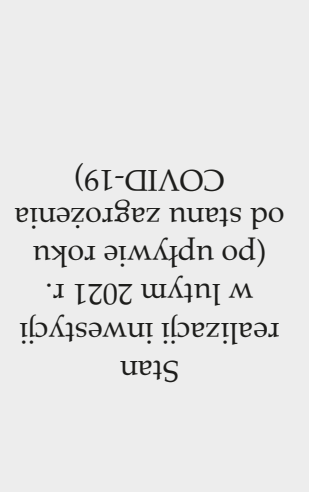 & 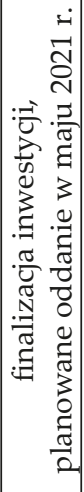 & 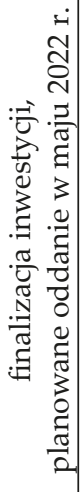 & 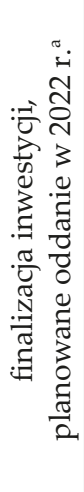 & 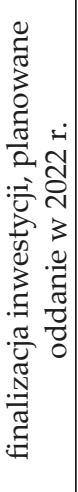 & 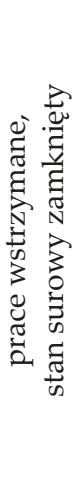 & 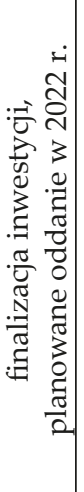 & 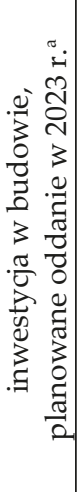 & 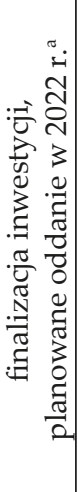 & 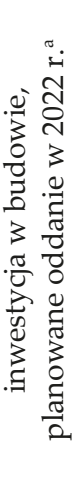 & 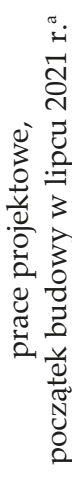 \\
\hline${ }_{\tau} \mathrm{U}$ емоэ$\left[+\Lambda \mathrm{Zn} \cdot \mathrm{MO}_{\mathrm{d}}\right.$ & $\begin{array}{l}8 \\
8 \\
0 \\
0\end{array}$ & $\begin{array}{l}8 \\
8 \\
10\end{array}$ & $\begin{array}{l}8 \\
8 \\
0\end{array}$ & 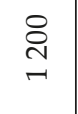 & 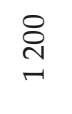 & $\begin{array}{l}8 \\
\varnothing \\
\circ\end{array}$ & $\begin{array}{l}8 \\
\varnothing \\
\end{array}$ & $\begin{array}{l}8 \\
8 \\
10\end{array}$ & $\begin{array}{l}8 \\
10 \\
-1\end{array}$ & $\begin{array}{l}8 \\
\stackrel{1}{1} \\
=\end{array}$ \\
\hline 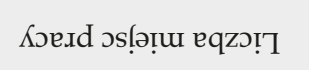 & \&্ণ & 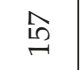 & $\stackrel{2}{N}$ & 6 & $\stackrel{M}{\sim}$ & $\stackrel{\mathscr{Z}}{\exists}$ & 离 & $\stackrel{2}{N}$ & $\stackrel{\infty}{\infty}$ & హ̄ \\
\hline 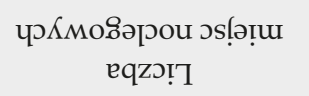 & $\underset{\infty}{\varnothing}$ & $\stackrel{\infty}{\not}$ & లి & 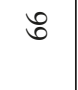 & 오 & ని & $\begin{array}{l}8 \\
\infty \\
-1\end{array}$ & $\underset{\sim}{\stackrel{\sim}{ }}$ & $\stackrel{8}{\circ}$ & 을 \\
\hline 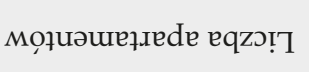 & 0 & 0 & $\underset{ }{\circ}$ & ฟ & 요 & $\stackrel{0}{10}$ & 0 & 0 & 0 & 0 \\
\hline $\begin{array}{c}\text { чрКмогәұоч Үәғsоupə! } \\
\text { еqzว!] }\end{array}$ & 아 & ڤેे & 0 & 0 & 0 & $\stackrel{\text { ㅇ }}{\square}$ & $\begin{array}{l}\infty \\
\& \\
\stackrel{+}{0}\end{array}$ & 8 & ட̊ & $\stackrel{\stackrel{2}{\stackrel{2}{N}}}{ }$ \\
\hline$\left.{ }_{*}\right)$ рлериетs & $\underset{⿱ 亠 䒑}{*} \underset{x}{*}$ & $\underset{⿱ 亠 䒑}{*} \underset{x}{*}$ & 新 & 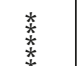 & $\stackrel{*}{*} \underset{*}{*}$ & 新 & \begin{tabular}{l}
$\underset{x}{*}$ \\
\multirow{x}{*}{}
\end{tabular} & 新 & 新 & $\begin{array}{l}\stackrel{*}{*} \underset{*}{*} \\
\stackrel{*}{*}\end{array}$ \\
\hline пঙүәтqо !еzроу & 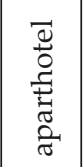 & 吾 & 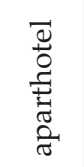 & 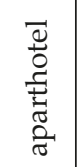 & एँ̃ & 吾 & 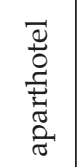 & 吾 & 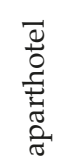 & تِّ \\
\hline пұঙәฺqо емzeN & $\begin{array}{c}\geq \\
\stackrel{0}{a} \\
\stackrel{\Xi}{0}\end{array}$ & 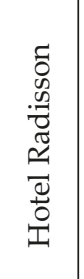 & 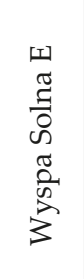 & 岕 & $\begin{array}{l}\hat{3} \\
3 \\
0 \\
0 \\
0 \\
3 \\
0\end{array}$ & $\begin{array}{l}\text { N } \\
\text { હे } \\
\text { ○े }\end{array}$ & 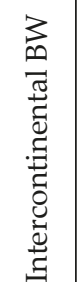 & 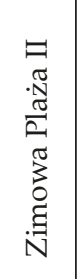 & 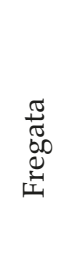 & 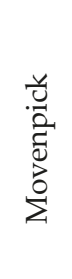 \\
\hline$\cdot \mathrm{d}_{\mathrm{T}}$ & $\neg$ & $N$ & $m$ & H & L & 6 & $\wedge$ & $\infty$ & $a$ & $\stackrel{\circ}{\circ}$ \\
\hline
\end{tabular}




\begin{tabular}{|c|c|c|c|c|c|c|c|c|c|c|}
\hline 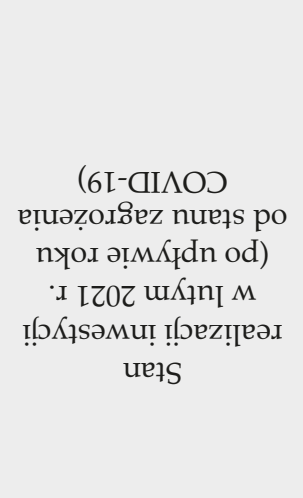 & 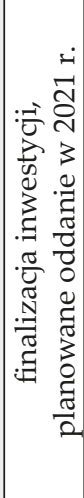 & 1 & 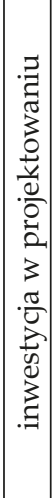 & 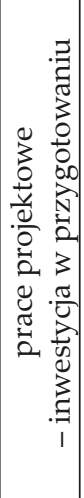 & 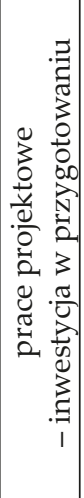 & 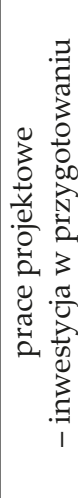 & 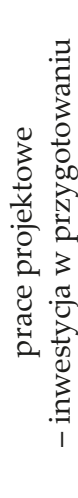 & 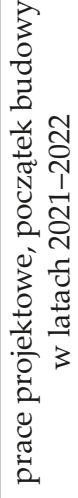 & 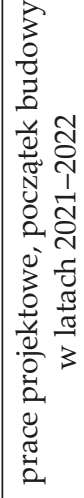 & 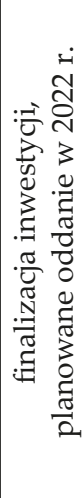 \\
\hline${ }_{z} \mathrm{U} \mathrm{\textrm {e }} \mathrm{MO}_{[} \Lambda \mathrm{z} \mathrm{n} \cdot \mathrm{MO}_{\mathrm{d}}$ & $\underset{\wp}{8}$ & \begin{tabular}{|c|}
8 \\
8 \\
+1 \\
10 \\
$\circ$ \\
-1
\end{tabular} & $\begin{array}{l}8 \\
i n \\
1\end{array}$ & $\begin{array}{l}8 \\
8 \\
\end{array}$ & $\begin{array}{l}8 \\
8 \\
10\end{array}$ & 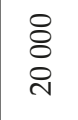 & $\begin{array}{l}8 \\
8 \\
10\end{array}$ & $\begin{array}{l}8 \\
8 \\
0 \\
\text { ల }\end{array}$ & $\begin{array}{l}8 \\
8 \\
8 \\
8\end{array}$ & 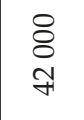 \\
\hline Кэеıd эs!ə!̣ eqzว!̣ & হ & $\stackrel{\vartheta}{=}$ & $\stackrel{m}{=}$ & 우 & 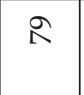 & $\stackrel{\infty}{\stackrel{\infty}{\sim}}$ & $\stackrel{m}{=}$ & $\stackrel{\vec{n}}{\mathrm{~N}}$ & $\stackrel{0}{=}$ & 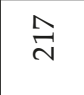 \\
\hline $\begin{array}{c}\text { чрКмовәроо эs!ə̣u } \\
\text { еqzว!̣ }\end{array}$ & $\stackrel{ }{\stackrel{ }{*}}$ & $\begin{array}{l}1 \\
\infty \\
\infty \\
10\end{array}$ & 各 & $\stackrel{\infty}{\not}$ & $\stackrel{ }{\text { ㄱ. }}$ & $\underset{n}{2}$ & ষ্ণ & $\stackrel{10}{8}$ & 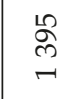 & $\underset{\infty}{\mathbb{N}}$ \\
\hline 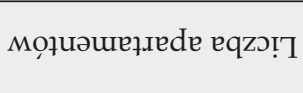 & 0 & Ғ & 0 & $\stackrel{8}{\circ}$ & 0 & 음 & 0 & 0 & 낭 & $\stackrel{\sim}{\sim}$ \\
\hline 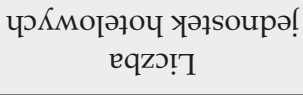 & $\stackrel{\text { L }}{O}$ & 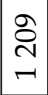 & 织 & 0 & $\stackrel{ }{O}$ & 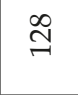 & 음 & 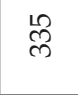 & 0 & 今 \\
\hline$\left.{ }_{*}\right)$ рлериетS & 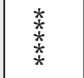 & 1 & $\underset{⿱ 亠 䒑}{*}$ & $\underset{\substack{* \\
⿱ 乛}}{\stackrel{*}{*}}$ & $\underset{\substack{* \\
⿱ 乛}}{\stackrel{*}{*}}$ & $\underset{\substack{* \\
⿱ 乛}}{\stackrel{*}{*}}$ & $\begin{array}{l}\frac{*}{x} \\
\frac{x}{x} \\
x\end{array}$ & $\underset{\substack{* \\
⿱ 亠 䒑 \\
x}}{\stackrel{x}{x}}$ & $\begin{array}{l}x \\
x \\
x \\
x \\
x\end{array}$ & $\begin{array}{l}\frac{*}{*} \\
x \\
x \\
x \\
x\end{array}$ \\
\hline пүәэтqо !еzроу & ت્ટ & 1 & 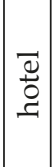 & 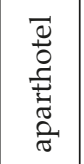 & 吾 & 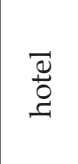 & تِّ & ت & 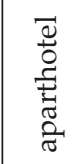 & تِ \\
\hline 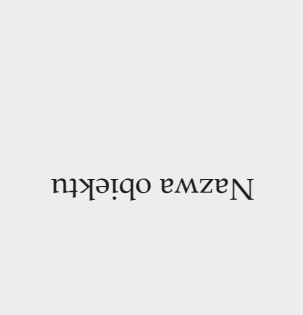 & 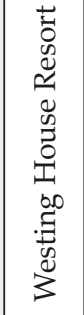 & 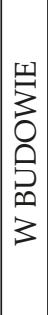 & 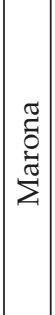 & 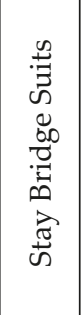 & 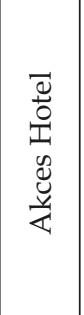 & 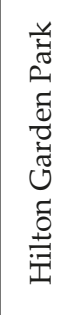 & 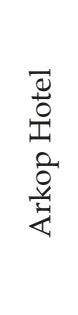 & 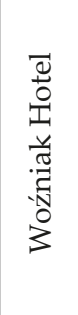 & 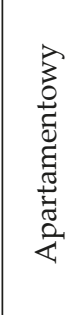 & 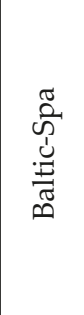 \\
\hline$\cdot \mathrm{d}_{7}$ & 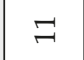 & & - & $N$ & $m$ & 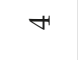 & เ & 6 & $\wedge$ & $\infty$ \\
\hline
\end{tabular}




\begin{tabular}{|c|c|c|c|c|c|c|c|c|c|c|c|c|c|c|c|c|c|c|c|c|c|}
\hline 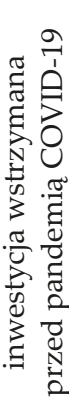 & 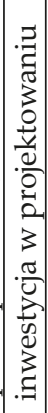 & 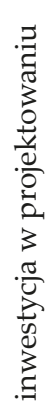 & 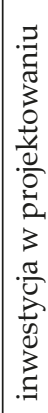 & 1 & 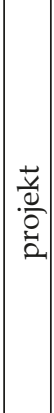 & 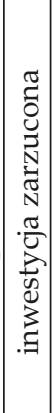 & $\mid \begin{array}{c}\vec{z} \\
\frac{\overrightarrow{0}}{0} \\
\frac{0}{0} \\
0 \\
\end{array}$ & 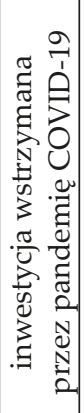 & 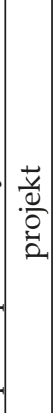 & $\begin{array}{l}\frac{\vec{v}}{d} \\
\frac{\vec{d}}{0} \\
\underline{\partial}\end{array}$ & $\mid \begin{array}{l}\vec{y} \\
\frac{0}{0} \\
\frac{a}{2} \\
\end{array}$ & 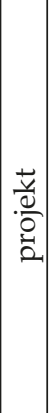 & 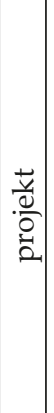 & $\mid$\begin{tabular}{|l}
$\vec{z}$ \\
$\frac{0}{0}$ \\
0 \\
0 \\
0
\end{tabular} & $\begin{array}{l}\frac{\vec{v}}{v} \\
\frac{\vec{d}}{2} \\
\vdots \\
0\end{array}$ & 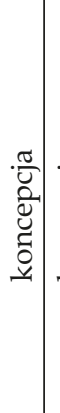 & 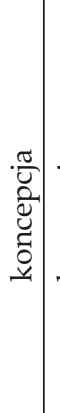 & 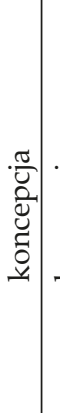 & 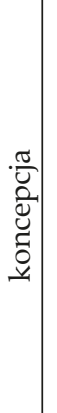 & 1 & 1 \\
\hline 8 & \begin{tabular}{|l|}
8 \\
8 \\
10
\end{tabular} & $\begin{array}{l}8 \\
8 \\
\wedge\end{array}$ & $\begin{array}{l}8 \\
8 \\
1\end{array}$ & $\begin{array}{l}8 \\
\text { مn } \\
\hat{\alpha} \\
\end{array}$ & 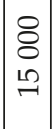 & \begin{tabular}{|c|}
8 \\
8 \\
$\stackrel{1}{2}$
\end{tabular} & $\begin{array}{c}8 \\
10 \\
\text { ㄱ. }\end{array}$ & $\begin{array}{l}8 \\
8 \\
10\end{array}$ & \begin{tabular}{|l|}
8 \\
8 \\
10
\end{tabular} & $\begin{array}{l}8 \\
8 \\
\wedge\end{array}$ & $\begin{array}{l}8 \\
8 \\
\text { เn }\end{array}$ & $\begin{array}{l}8 \\
8 \\
\forall \\
6\end{array}$ & $\begin{array}{l}8 \\
\varnothing \\
\infty\end{array}$ & \begin{tabular}{l|}
8 \\
8 \\
10 \\
1
\end{tabular} & 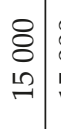 & 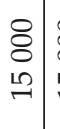 & $\begin{array}{l}8 \\
8 \\
\llcorner\end{array}$ & $\begin{array}{l}8 \\
8 \\
\stackrel{2}{N}\end{array}$ & $\begin{array}{l}8 \\
\& \\
\stackrel{2}{N}\end{array}$ & 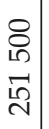 & 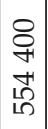 \\
\hline$\stackrel{\infty}{\infty}$ & $\stackrel{m}{=}$ & $\stackrel{\infty}{=}$ & $\stackrel{\infty}{=}$ & $\begin{array}{l}3 \\
3 \\
+ \\
-1\end{array}$ & $\stackrel{\leftrightarrow}{\sim}$ & ষ্ণ & \begin{tabular}{l|}
$\infty$ \\
$\infty$
\end{tabular} & 음 & $\stackrel{2}{=}$ & $\stackrel{\leftrightarrow}{N}$ & $\stackrel{\infty}{=}$ & $\begin{array}{l}\frac{20}{N} \\
\stackrel{n}{n}\end{array}$ & 迎 & $\infty$ & $\infty$ & 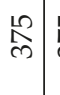 & $\underset{n}{n}$ & 옷 & 옹 & $\begin{array}{l}\infty \\
2 \\
n\end{array}$ & $\begin{array}{l}1 \\
\qquad \begin{array}{c}10 \\
0\end{array}\end{array}$ \\
\hline \& & ஓి & ஓ్ల & \&্ণ & \begin{tabular}{|c|}
$\infty$ \\
$\infty$ \\
10 \\
10
\end{tabular} & 8 & $\underset{\infty}{\infty}$ & $\underset{-}{8}$ & 음 & ষ্ণ & 8 & $\begin{array}{l}8 \\
\text { ¿ }\end{array}$ & $\underset{8}{8}$ & $\underset{\sim}{\stackrel{\sim}{ }}$ & $\begin{array}{l}8 \\
\stackrel{10}{+1}\end{array}$ & 号 & $\underset{8}{8}$ & $\begin{array}{l}8 \\
8 \\
-1\end{array}$ & $\begin{array}{l}8 \\
\varnothing \\
\sim\end{array}$ & $\begin{array}{l}8 \\
\stackrel{8}{ } \\
\sim\end{array}$ & $\begin{array}{l}\text { 온 } \\
10 \\
=\end{array}$ & 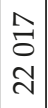 \\
\hline 0 & 0 & 0 & 0 & 首 & 0 & 0 & 0 & 유 & 0 & 0 & 0 & 0 & 0 & \begin{tabular}{|l|}
$\stackrel{\circ}{\circ}$ \\
\end{tabular} & 呙 & \begin{tabular}{l|l}
0 &
\end{tabular} & 0 & \begin{tabular}{l|l}
0 & 0
\end{tabular} & 0 & \begin{tabular}{l|}
$\circ$ \\
10 \\
7
\end{tabular} & $\begin{array}{l}0 \\
\text { જ̊ } \\
-1\end{array}$ \\
\hline$\stackrel{\circ}{\stackrel{1}{N}}$ & 욤 & 요 & 욤 & $\begin{array}{l}10 \\
\infty \\
-1 \\
\end{array}$ & 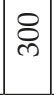 & \&্+ & in & 음 & 员 & ஓ্ণ & 点 & $\begin{array}{l}8 \\
i \\
i n\end{array}$ & 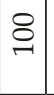 & 0 & 0 & \&ి & $\begin{array}{l}8 \\
\circ \\
1\end{array}$ & $\begin{array}{c}8 \\
\varnothing \\
-\end{array}$ & 8 & $\begin{array}{l}8 \\
\stackrel{1}{1} \\
\text { in }\end{array}$ & 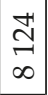 \\
\hline \begin{tabular}{l}
$*$ \\
\multirow{*}{*}{} \\
$*$
\end{tabular} & 1 & 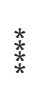 & $\underset{*}{*}$ & 1 & $\frac{x}{x}$ & $\underset{x}{*}$ & $\begin{array}{l}x \\
x \\
x \\
x \\
x \\
x\end{array}$ & 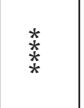 & \begin{tabular}{|l}
$*$ \\
\multirow{2}{*}{} \\
\multirow{*}{*}{} \\
\multirow{2}{*}{}
\end{tabular} & $\begin{array}{l}\frac{x}{x} \\
\frac{x}{x} \\
\end{array}$ & 妾 & $\begin{array}{l}x \\
⿱ x \\
x \\
x\end{array}$ & $\underset{x}{x}$ & $\frac{x}{x}$ & $\frac{x}{x}$ & 类 & 索 & $\frac{x}{x}$ & 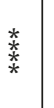 & I & 1 \\
\hline एँ & 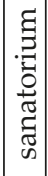 & 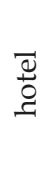 & 吾 & 1 & $\mid \begin{array}{l}\bar{g} \\
0 \\
c\end{array}$ & $\begin{array}{l}\vec{\Xi} \\
0 \\
0\end{array}$ & $\mid \begin{array}{l}\bar{y} \\
0 \\
c\end{array}$ & & 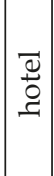 & $\mid \begin{array}{l}\vec{\Phi} \\
0 \\
0\end{array}$ & 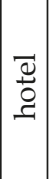 & 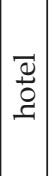 & 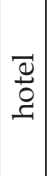 & 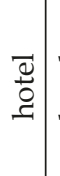 & 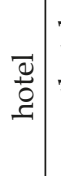 & 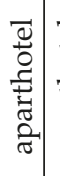 & 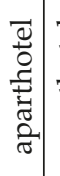 & 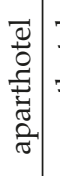 & 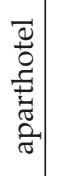 & 1 & 1 \\
\hline 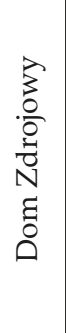 & 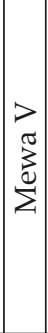 & 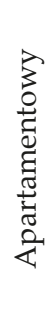 & 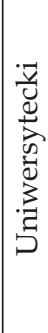 & 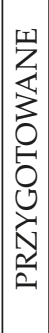 & 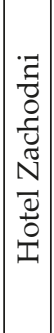 & $\mid \begin{array}{l}0.0 \\
\tilde{N} \\
0 \\
0 \\
0 \\
\overrightarrow{0} \\
\underline{y} \\
3 \\
0 \\
0 \\
0\end{array}$ & 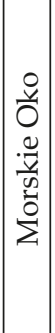 & 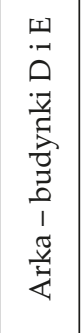 & $\mid \begin{array}{l}\overrightarrow{9} \\
0 \\
0 \\
0\end{array}$ & $\begin{array}{l}\tilde{J} \\
\tilde{J} \\
\tilde{d} \\
\tilde{0} \\
\tilde{\sigma} \\
\tilde{0} \\
\Sigma\end{array}$ & 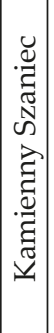 & 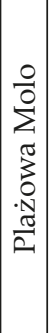 & 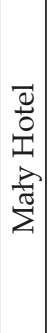 & 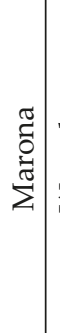 & $\begin{array}{l}\frac{\pi}{0} \\
\vec{d} \\
\tilde{D} \\
3\end{array}$ & 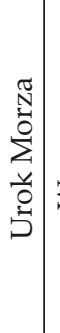 & 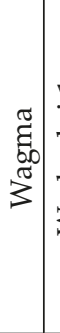 & 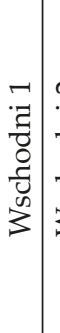 & 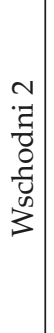 & 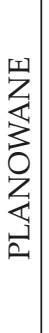 & 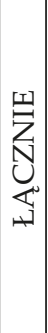 \\
\hline$a$ & 의 & $\exists$ & $\approx$ & & - & $N$ & $\infty$ & + & $\infty n$ & 6 & $\wedge$ & $\infty$ & a & 음 & $\exists$ & $\underset{\sim}{\sim}$ & $\stackrel{m}{\sim}$ & \pm & $\stackrel{\operatorname{Ln}}{\sim}$ & & \\
\hline
\end{tabular}




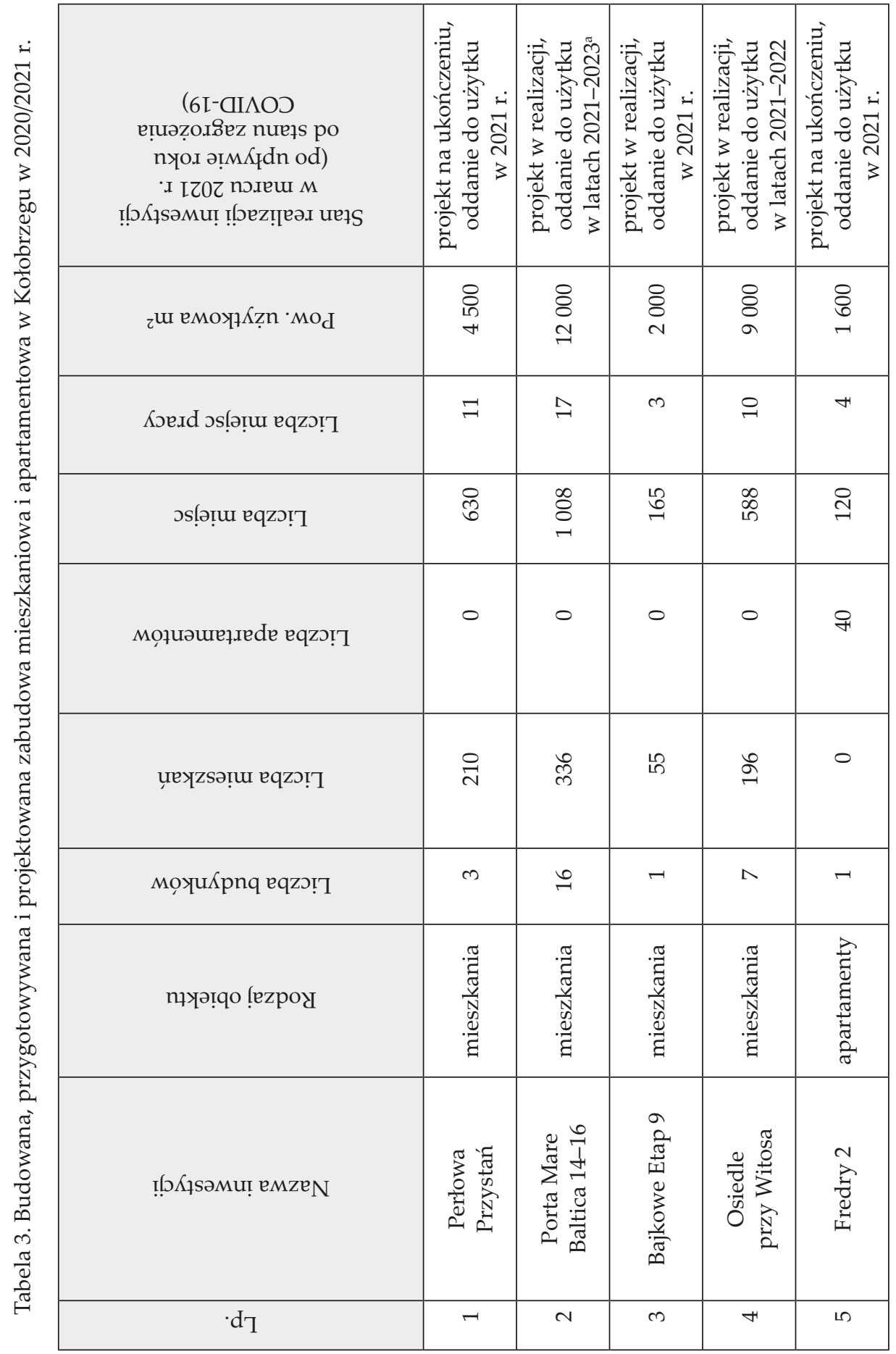




\begin{tabular}{|c|c|c|c|c|c|c|c|c|}
\hline 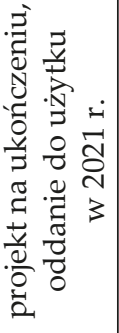 & 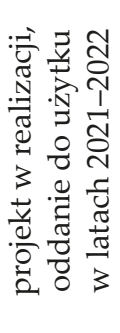 & 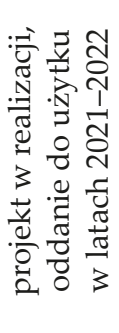 & 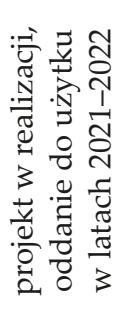 & 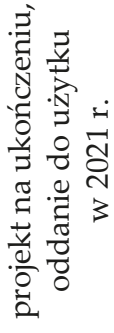 & 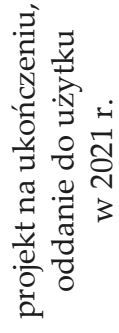 & 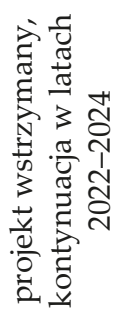 & 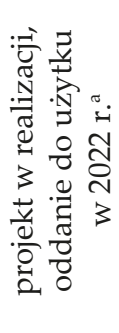 & 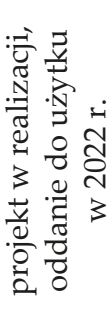 \\
\hline$\underset{8}{8}$ & $\begin{array}{l}8 \\
\stackrel{1}{1} \\
\text { N }\end{array}$ & $\begin{array}{l}8 \\
\varnothing \\
\text { m }\end{array}$ & $\begin{array}{l}8 \\
8 \\
\stackrel{-}{7}\end{array}$ & $\begin{array}{l}8 \\
\text { రి } \\
\text { m }\end{array}$ & $\begin{array}{l}8 \\
\varnothing \\
\infty\end{array}$ & $\begin{array}{l}8 \\
8 \\
10\end{array}$ & $\begin{array}{l}8 \\
\varnothing \\
\infty\end{array}$ & $\begin{array}{l}8 \\
\varnothing \\
\infty\end{array}$ \\
\hline$n$ & $m$ & $m$ & 0 & $N$ & ฟ & $\stackrel{m}{\sim}$ & $\rightleftarrows$ & $a$ \\
\hline 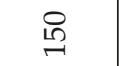 & 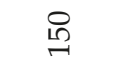 & $\stackrel{2}{2}$ & 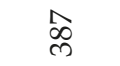 & 곡 & हु & 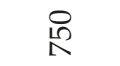 & ్ㅗㄱ & $\stackrel{\stackrel{\llcorner}{2}}{\sim}$ \\
\hline 0 & 0 & 0 & 0 & 0 & $\stackrel{\infty}{\underset{\sim}{\sim}}$ & 0 & 요 & 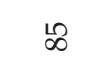 \\
\hline in & เి & 18 & సิ & 아 & 0 & ڤి & 0 & 0 \\
\hline$\neg$ & $N$ & - & নे & ㅇ & $N$ & 10 & $\neg$ & $r$ \\
\hline 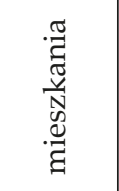 & 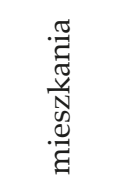 & 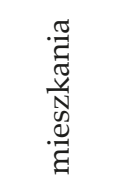 & $\begin{array}{l}\vec{\Xi} \\
\text { ठ }\end{array}$ & $\begin{array}{l}\vec{\Xi} \\
\text { ठ } \\
\text { ర }\end{array}$ & 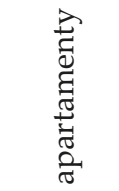 & 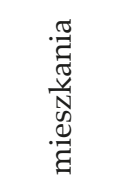 & 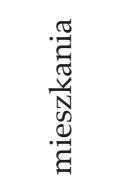 & 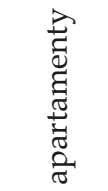 \\
\hline 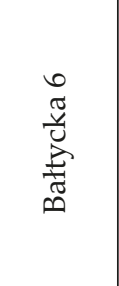 & 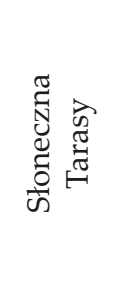 & 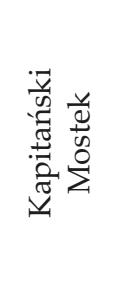 & 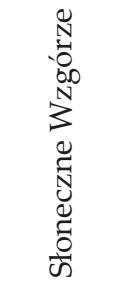 & 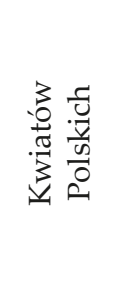 & 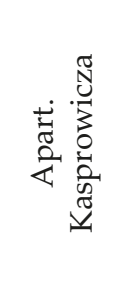 & 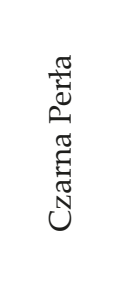 & 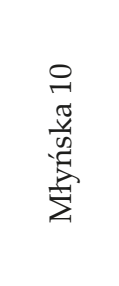 & 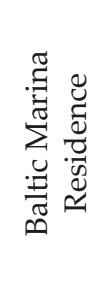 \\
\hline 0 & $\Lambda$ & $\infty$ & $a$ & $\stackrel{-}{\circ}$ & $\exists$ & $\stackrel{\sim}{\sim}$ & $\stackrel{M}{\sim}$ & 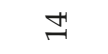 \\
\hline
\end{tabular}




\begin{tabular}{|c|c|c|c|c|c|}
\hline 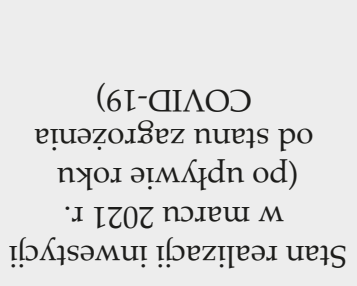 & 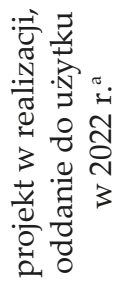 & 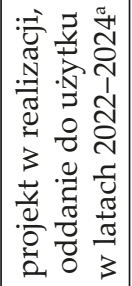 & 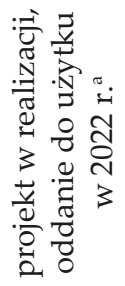 & 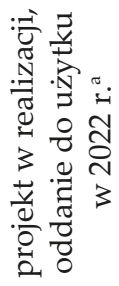 & 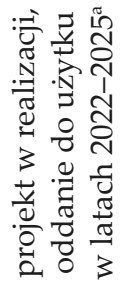 \\
\hline 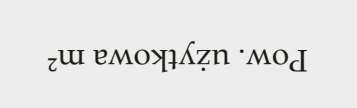 & $\begin{array}{l}8 \\
\stackrel{1}{1} \\
\wedge\end{array}$ & $\begin{array}{l}8 \\
10 \\
\text { I } \\
7\end{array}$ & 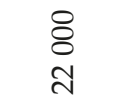 & $\begin{array}{l}\stackrel{8}{8} \\
\sim\end{array}$ & \begin{tabular}{l}
8 \\
8 \\
\multirow{2}{*}{}
\end{tabular} \\
\hline 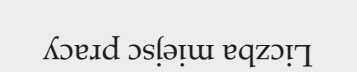 & $\infty$ & $\stackrel{\infty}{\sim}$ & $H$ & ○ & $\stackrel{10}{\infty}$ \\
\hline 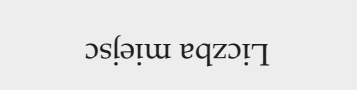 & ஜ̊ & $\begin{array}{l}\stackrel{0}{1} \\
0 \\
-\end{array}$ & $\underset{m}{\vec{m}}$ & $\vec{\infty}$ & ஓু \\
\hline 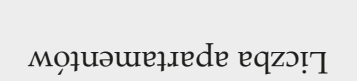 & 0 & 0 & कु & તิ & 0 \\
\hline 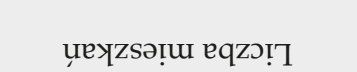 & 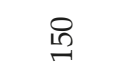 & 오 & 0 & 0 & ৪্ণ \\
\hline 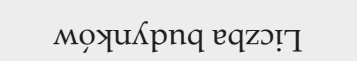 & $m$ & 10 & 10 & - & $\stackrel{ }{-1}$ \\
\hline пґҮәтqо !еzроу & 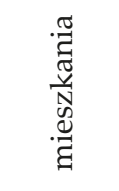 & 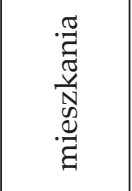 & 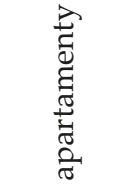 & 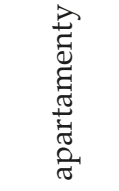 & 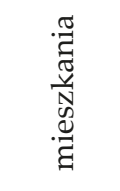 \\
\hline 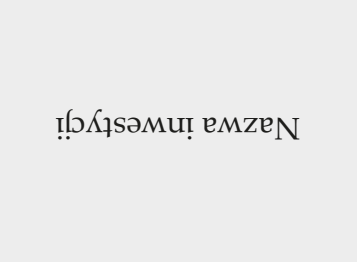 & 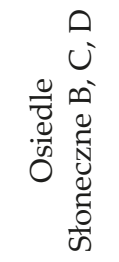 & 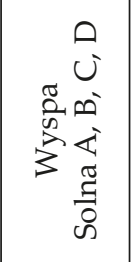 & 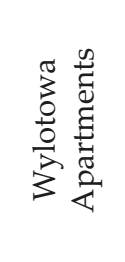 & 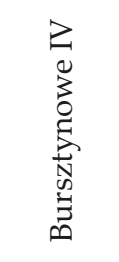 & 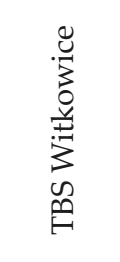 \\
\hline$\cdot d_{7}$ & $\stackrel{20}{\sim}$ & $\stackrel{0}{\sim}$ & $\bumpeq$ & $\stackrel{\infty}{\sim}$ & $\stackrel{\vartheta}{\sim}$ \\
\hline
\end{tabular}




\begin{tabular}{|c|c|c|c|c|c|c|c|c|c|c|}
\hline 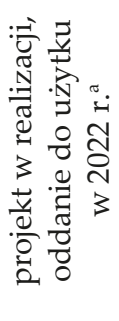 & 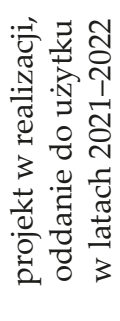 & 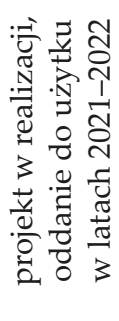 & 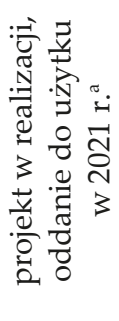 & 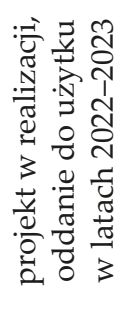 & 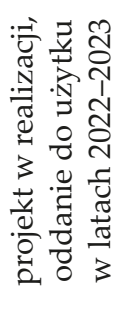 & 1 & 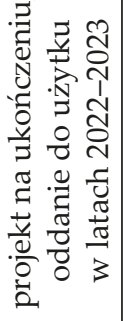 & 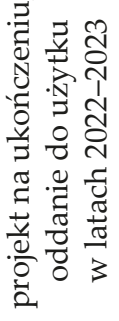 & 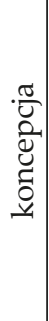 & 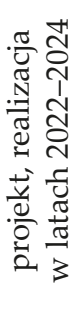 \\
\hline$\underset{\wedge}{8}$ & $\begin{array}{l}8 \\
8 \\
\text { m }\end{array}$ & $\begin{array}{l}8 \\
8 \\
\end{array}$ & $\begin{array}{l}8 \\
8 \\
10\end{array}$ & $\begin{array}{l}8 \\
8 \\
\stackrel{2}{0}\end{array}$ & $\begin{array}{l}8 \\
8 \\
\nexists \\
\not\end{array}$ & 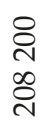 & $\begin{array}{l}8 \\
8 \\
\stackrel{2}{N}\end{array}$ & $\begin{array}{l}8 \\
8 \\
10\end{array}$ & 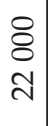 & $\begin{array}{l}8 \\
8 \\
10 \\
\sim\end{array}$ \\
\hline- & 10 & H & $\infty$ & 으 & 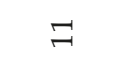 & $\stackrel{10}{\circ}$ & $a$ & L & $\stackrel{\sim}{~}$ & $\stackrel{m}{=}$ \\
\hline$\stackrel{\circ}{\stackrel{ }{\sim}}$ & ষ্ণ & $\underset{\sim}{\stackrel{\overbrace{}}{\text { \} }}} &{\stackrel{10}{\circ}} &{\text { ৪ి }} &{\text { ๑ి }} &{\begin{array}{l}\text { a) } \\
\text { เn } \\
\text { N }\end{array}} &{\text { के }} &{\text { ষ্ণ }} &{\text { 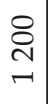 }} &{\stackrel{\circ}{\circ}} \\
{\hline R} &{0} &{\underset{+}{8}} &{0} &{0} &{0} &{\underset{\sim}{\stackrel{ }{F}}} &{0} &{0} &{0} &{0} \\
{\hline 0} &{8} &{0} &{\text { 늠 }} &{\underset{\text { ¿ }}{\stackrel{\text { }}{2}}} &{\text { సి }} &{\text { 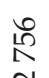 }} &{\stackrel{\infty}{=}} &{\stackrel{8}{8}} &{\text { \&্ণ }} &{\text { 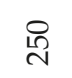 }} \\
{\hline \neg} &{N} &{N} &{-} &{H} &{-} &{\text { I }} &{-} &{\neg} &{N} &{10} \\
{\hline \text { 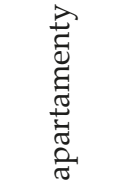 }} &{\text { 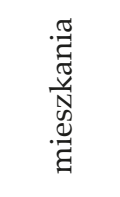 }} &{\text { 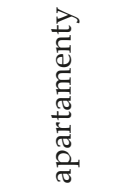 }} &{\text { 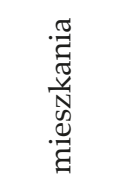 }} &{\text { 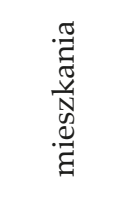 }} &{\text { 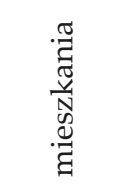 }} &{1} &{\text { 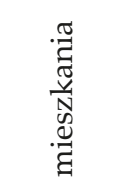 }} &{\text { 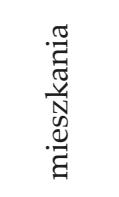 }} &{\text { 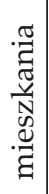 }} &{\text { 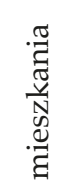 }} \\
{\hline \text { 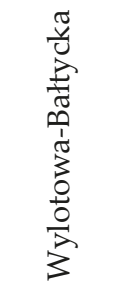 }} &{\text { 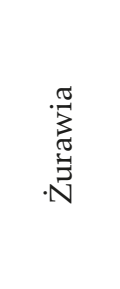 }} &{\text { 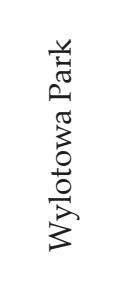 }} &{\text { 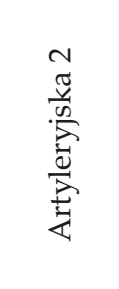 }} &{\text { 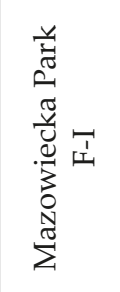 }} &{\text { 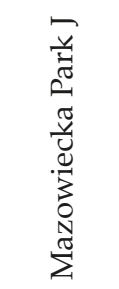 }} &{\begin{array}{l}3 \\
3 \\
3 \\
3 \\
3 \\
3 \\
3 \\
3\end{array}} &{\begin{array}{l}\frac{\pi}{3} \\
0 \\
0 \\
0 \\
0 \\
0\end{array}} &{\text { 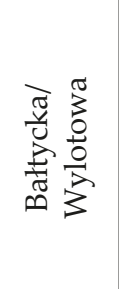 }} &{\text { 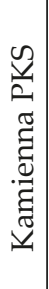 }} &{\text { 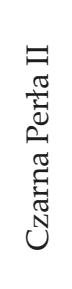 }} \\
{\hline \text { ㄱ. }} &{\vec{\sim}} &{\text { ন }} &{\ddot{N}} &{\mathbb{d}} &{\stackrel{\llcorner}{\sim}} &{ } &{-} &{\sim} &{n} &{H} \\
$\hline
\end{tabular}




\begin{tabular}{|c|c|c|c|c|c|c|c|}
\hline 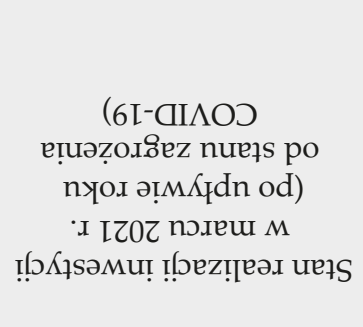 & 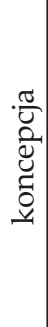 & 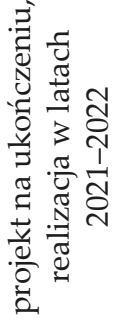 & 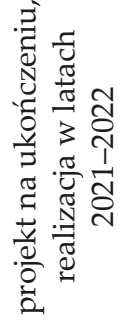 & 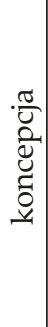 & 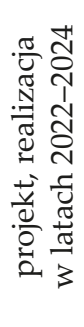 & 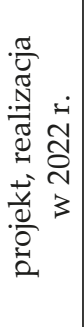 & 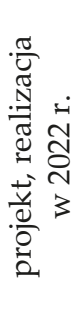 \\
\hline 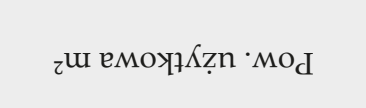 & 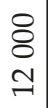 & $\begin{array}{l}8 \\
8 \\
10\end{array}$ & $\begin{array}{l}8 \\
8 \\
\circ\end{array}$ & $\begin{array}{l}8 \\
8 \\
\llcorner \\
\stackrel{1}{n}\end{array}$ & $\begin{array}{l}8 \\
8 \\
\circ \\
\text { டn }\end{array}$ & $\begin{array}{l}8 \\
8 \\
10 \\
\stackrel{1}{n}\end{array}$ & $\begin{array}{l}8 \\
\text { ळ }\end{array}$ \\
\hline 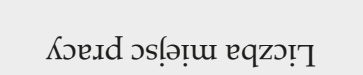 & $\underset{ت}{\sharp}$ & \llcorner & $a$ & $\stackrel{\sim}{\sim}$ & $\stackrel{\sim}{\sim}$ & $N$ & $\circ$ \\
\hline วs!̣ı̣u eqzọ̣] & 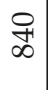 & $\frac{10}{\infty}$ & ㅇํ & $\stackrel{\nwarrow}{\Sigma}$ & $\begin{array}{l}8 \\
\text { เి } \\
\end{array}$ & ని & \& \\
\hline 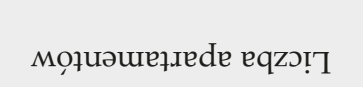 & 0 & 0 & 0 & 0 & 0 & 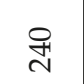 & ిి \\
\hline ự ’Zsə!̣u eqzo!̣] & $\begin{array}{l}\stackrel{\infty}{N} \\
\text { N }\end{array}$ & 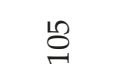 & $\stackrel{\infty}{\infty}$ & $\stackrel{\text { I }}{\mathrm{N}}$ & \&ి & 0 & 0 \\
\hline 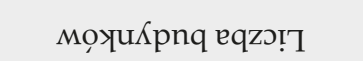 & - & - & $\sim$ & $H$ & 10 & N & - \\
\hline пґҮәтqо !еzроу & 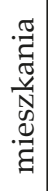 & 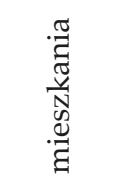 & 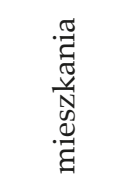 & 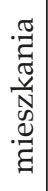 & 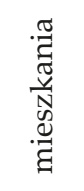 & 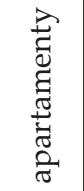 & 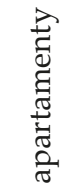 \\
\hline 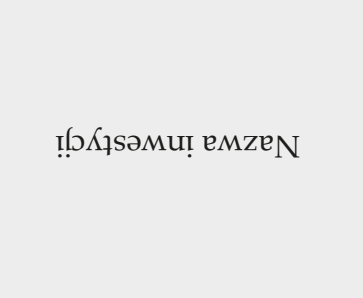 & 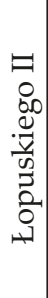 & 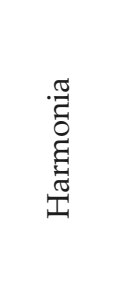 & 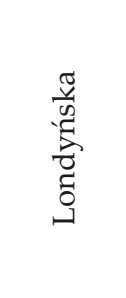 & 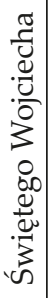 & 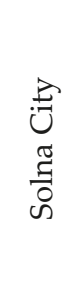 & 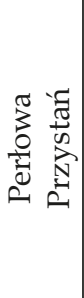 & $\begin{array}{l}\text { J } \\
\text { Uू } \\
0\end{array}$ \\
\hline$\cdot d_{7}$ & เn & 6 & $\Lambda$ & $\infty$ & $a$ & $ㅇ$ & $\exists$ \\
\hline
\end{tabular}




\begin{tabular}{|c|c|c|c|c|c|c|c|c|c|c|c|c|}
\hline 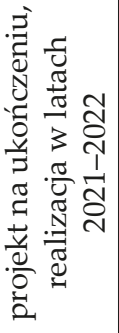 & 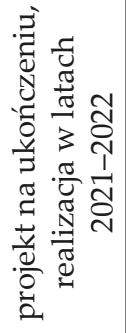 & 1 & 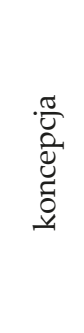 & $\begin{array}{l}\cdot \frac{\pi}{0} \\
0 \\
0 \\
0 \\
0 \\
0 \\
y\end{array}$ & $\begin{array}{l}\cdot \tilde{\sigma} \\
\tilde{0} \\
\tilde{z} \\
\tilde{U} \\
\tilde{0} \\
\underline{v}\end{array}$ & 1 & 1 & 1 & 1 & 1 & 1 & 1 \\
\hline 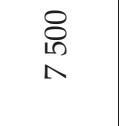 & $\stackrel{8}{\circledR}$ & 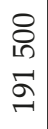 & $\begin{array}{l}8 \\
8 \\
\text { டி }\end{array}$ & $\begin{array}{l}8 \\
8 \\
8 \\
10\end{array}$ & \begin{tabular}{l}
8 \\
8 \\
0 \\
\hdashline
\end{tabular} & $\begin{array}{l}8 \\
8 \\
\circ \\
\ddots\end{array}$ & $\begin{array}{l}8 \\
尺 \\
\text { aे } \\
\text { மn }\end{array}$ & 完 & $\begin{array}{l}8 \\
8 \\
m \\
m\end{array}$ & $\begin{array}{l}8 \\
8 \\
\infty \\
\infty \\
\text { ల }\end{array}$ & $\begin{array}{l}8 \\
\text { 10 } \\
\overline{0} \\
\text { ल }\end{array}$ & 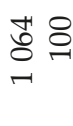 \\
\hline$N$ & $\neg$ & $\stackrel{\triangleq}{ }$ & เి & ○ & 음 & $\stackrel{\circ}{\rightleftharpoons}$ & ิ & 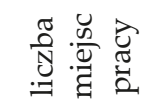 & $\stackrel{2}{\sim}$ & $\begin{array}{l}0 \\
\infty \\
10 \\
-\end{array}$ & \begin{tabular}{l}
$\infty$ \\
\multirow{+}{*}{} \\
+
\end{tabular} & ळे \\
\hline ๙ิ & $\stackrel{10}{m}$ & 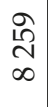 & $\begin{array}{l}8 \\
8 \\
m\end{array}$ & $\begin{array}{l}8 \\
8 \\
m\end{array}$ & 8 & $\begin{array}{l}8 \\
8 \\
0\end{array}$ & $\begin{array}{l}\infty \\
\text { N } \\
\text { Â }\end{array}$ & 芯 & 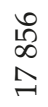 & $\begin{array}{l}\stackrel{9}{+} \\
\stackrel{+}{=}\end{array}$ & $\begin{array}{l}\infty \\
\infty \\
\infty \\
\infty \\
-1\end{array}$ & $\begin{array}{l}\stackrel{\text { I }}{7} \\
\text { ga }\end{array}$ \\
\hline 요 & $\stackrel{10}{\circ}$ & $\frac{10}{\square}$ & 0 & 0 & 0 & 0 & ๙̃ & 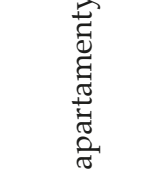 & $\begin{array}{l}\infty \\
\stackrel{\infty}{N} \\
\sim\end{array}$ & ๙ૂ & 옴 & $\begin{array}{l}\text { స్ర } \\
\text { m }\end{array}$ \\
\hline 0 & 0 & $\begin{array}{l}\infty \\
\stackrel{\sim}{N} \\
\sim\end{array}$ & $\stackrel{8}{8}$ & 8 & 尺) & $\begin{array}{l}\text { ㄱ } \\
\text { N }\end{array}$ & 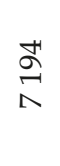 & 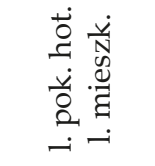 & $\begin{array}{l}18 \\
\text { o } \\
0\end{array}$ & $\stackrel{0}{0}$ & $\begin{array}{l}8 \\
\infty \\
n\end{array}$ & $\begin{array}{l}\infty \\
\infty \\
1 \\
\stackrel{1}{n}\end{array}$ \\
\hline$\sim$ & 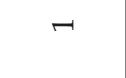 & 1 & $\wedge$ & $\sim$. & $\sim$. & 1 & 1 & 1 & 1 & 1 & 1 & 1 \\
\hline 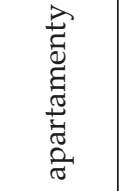 & 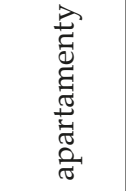 & 1 & 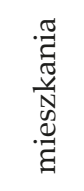 & 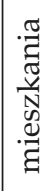 & 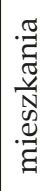 & 1 & 1 & 1 & 1 & 1 & 1 & 1 \\
\hline 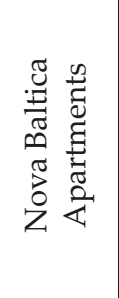 & 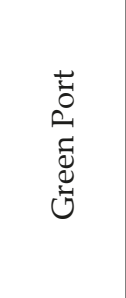 & 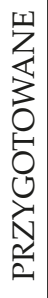 & 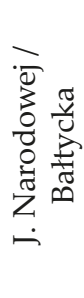 & 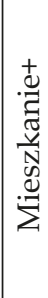 & 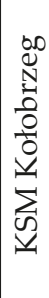 & 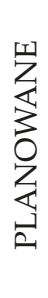 & 岂 & 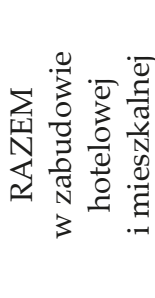 & $\begin{array}{l}1 \\
3 \\
3 \\
3 \\
3 \\
3 \\
3\end{array}$ & 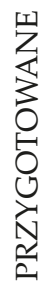 & 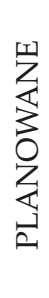 & 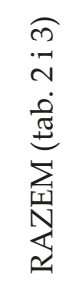 \\
\hline $\mathcal{\sim}$ & $\stackrel{m}{\sim}$ & & - & $N$ & $m$ & & & & & & & \\
\hline
\end{tabular}




\section{Podsumowanie}

Kołobrzeg jako największe polskie uzdrowisko, a jednocześnie kluczowy kurort nadmorski, dotychczas przez wiele lat funkcjonował przez cały rok, natomiast różnica wielkości ruchu turystycznego między tzw. miesiącami szczytu sezonu letniego a pozostałymi miesiącami roku zmalała tu do niespełna $30 \%$. Można zatem stwierdzić, że jest to obszar turystyczny nie tylko o jednym z najwyższych wskaźników obłożenia bazy noclegowej (do wprowadzenia stanu zagrożenia COVID-19 w 2020 r. - średnio rocznie ok. $70 \%$ ), ale także czołowy obszar koncentracji turystycznej i okołoturystycznej bazy noclegowej w formie co najmniej kilkunastu, a niedługo kilkudziesięciu tysięcy mieszkań i apartamentów. W wyniku oddziaływania bezpośredniego i pośredniego COVID-19 wpływy z opłaty uzdrowiskowej zmalały w 2020 r. o 36,2\% z przewidywanych 17 mln zł do niespełna 10,9 mln zł. Łącznie $z$ innymi podatkami lokalnymi, zmniejszonymi udziałami w podatkach PIT i CIT, a także z tytułu niższych stawek dzierżaw dochody budżetu miasta zmalały o ponad 18 mln zł (stan na 11.11.2020 r.) (Informacje Kołobrzeg.pl, 2020), co oznaczało spadek dochodów miasta o ok. 7-8\%. Z kolei bezrobocie w powiecie kołobrzeskim po upływie roku z poziomu 1,4\% wzrosło do $6 \%$, minimalnie przekraczając poziom $\mathrm{tzw}$. bezrobocia naturalnego. $\mathrm{Z}$ kolei rynek hotelowy, apartamentowy i mieszkaniowy w przypadku Kołobrzegu zareagował znaczącą zwyżką cen, zgodnie z oczekiwaniami większości inwestorów. Miasto to w 2019 r. osiągnęło maksymalny poziom rozwoju funkcji uzdrowiskowo-turystycznych przy znaczącym zachwianiu proporcji i równowagi przestrzenno-funkcjonalnej i społeczno-gospodarczej.

Podsumowując, można zatem pokusić się o stwierdzenie, że: bezprecedensowe okresowe spadki wielkości ruchu turystycznego (w niektórych miesiącach o ponad 95\%), spadek dochodów budżetu miasta (o 7-8\%), minimalna nadwyżka budżetowa za $2020 \mathrm{r}$. (+2,9 mln zł wobec $+16,1 \mathrm{mln}$ zł za 2019 r.) (Bilans z wykonania budżetu za 2020 r., 2020) głównie dzięki ograniczeniu inwestycji przy znaczącym wzroście bezrobocia $(+4,5 \%)$ wymusiły na władzach i mieszkańcach miasta podjęcie bardzo poważnych działań, zmierzających do dywersyfikacji i przebudowy struktury przestrzennej i funkcjonalnej miasta (zlecono wykonanie Studium możliwości poszerzenia profilu gospodarczego miasta Kołobrzeg i wskazanie ścieżki jego wdrożenia). W ramach podejmowanych działań przewiduje się opracowanie koncepcji rozległych zmian granic administracyjnych, rozwoju 
nieuciążliwych funkcji portowych i usług przemysłowych, a także kreowania „znakomitego miejsca do życia” i „,bezpiecznej przystani” spośród największych rynków turystycznych i uzdrowiskowych kraju. Pandemia COVID-19 okazała się silnie stymulującym impulsem do zmian strukturalnych, przestrzennych, funkcjonalnych i społeczno-gospodarczych, które umożliwią docelowo przekształcenie ,jednoimiennej gospodarki wielkiego nadmorskiego kurortu" w nowoczesne wielofunkcyjne miasto nadmorskie o zróżnicowanych funkcjach społecznych i gospodarczych.

\section{Bibliografia}

Bank Danych Lokalnych (2021). Pobrane z: https://bdl.stat.gov.pl/BDL/dane/podgrup/ tablica (10.07.2021).

Bilans z wykonania budżetu za 2020 r. (2020). Biuletyn Informacji Publicznej. Urząd Miasta Kołobrzeg. Pobrane z: http://umkolobrzeg.esp.parseta.pl/index.php?id=127921 (29.03.2021).

Davahli, R.M., Karwowski, W., Sonmez, S., Apostolopoulos, Y. (2020). The hospitality industry in the face of the COVID-19 pandemic: Current topic and research methods. International Journal of Environmental Research and Public Health, 17, 7366. https://doi. org/10.3390/ijerph17207366

Flores-Ruiz, D., Elizondo-Salto, A., Barroso-González, M.d.1.O. (2021). Using social media in tourist sentiment analysis: A case study of andalusia during the Covid-19 pandemic. Sustainability, 13, 3836. https://doi.org/10.3390/su13073836

Foo, L.-P., Chin, M.-Y., Tan, K.-L., Phuah, K.-T. (2020). The impact of COVID-19 on tourism industry in Malaysia. Current Issues in Tourism, 2020, 1-5. https://doi.org/10.1080/136 83500.2020.1777951

Fotiadis, A., Polyzos, S., Huan, T.-C.T.C. (2021). The good, the bad and the ugly on COVID-19 tourism recovery. Annals of Tourism Research, 87, 103117. https://doi. org/10.1016/j.annals.2020.103117

Główny Urząd Statystyczny (2020). Obrót nieruchomościami w 2019 r. Pobrane z: https://stat. gov.pl/obszary-tematyczne/infrastruktura-komunalna-nieruchomosci/nieruchomosci-budynki-infrastruktura-komunalna/obrot-nieruchomosciami-w-2019-roku,8,3.html (29.03.2021).

Główny Urząd Statystyczny (2021). Turystyka w 2020 roku. Pobrane z: https://stat.gov.pl/ obszary-tematyczne/kultura-turystyka-sport/turystyka/turystyka-w-2020-roku,1,18. html (31.06.2021).

Informacje Kołobrzeg.pl (2020). Pobrane z: https://www.informacje.kolobrzeg.pl/ miastokg/11504-prezydent-anna-mieczkowska-pisze-list-do-mieszkancow (27.03.2021).

Kowalska, K., Niezgoda, A. (2020). COVID-19 as a tourist activity inhibitor as evidenced by Poles' holiday plans. Studia Periegetica, 4 (32), 9-24. https://doi. org/10.5604/01.3001.0014.6526

Medexpress (2020). Pobrane z: https://www.medexpress.pl/minister-zdrowia-wstrzymal-swiadczenia-w-lecznictwie-uzdrowiskowym/76689 (27.03.2021). 
Medonet (2021). Pobrane z: https://www.medonet.pl/koronawirus/koronawirus-w-polsce,koronawirus-w-polsce--kim-byl-pacjent-zero--jak-sie-czuje-,artykul,21379457. html (28.03.2021).

Ministerstwo Rozwoju, Pracy i Technologii (2020). Pobrane z: https://www.gov.pl/web/ rozwoj-praca-technologia/spotkanie-wiceministra-andrzeja-guta-mostowego-z-przedstawicielami-gmin-uzdrowiskowych (28.03.2021).

Moreno-Luna, L., Robina-Ramírez, R., Sánchez, M.S.-O., Castro-Serrano, J. (2021). Tourism and sustainability in times of COVID-19: The case of Spain. International Journal of Environmental Research and Public Health, 18, 1859. https://doi.org/10.3390/ ijerph18041859

Narodowy Fundusz Zdrowia (2020a). Pobrane z: https://www.nfz.gov.pl/aktualnosci/ aktualnosci-oddzialow/wyjazd-do-sanatorium-odpowiadamy-na-najczesciej-zadawane-pytania,407.html (28.03.2021).

Narodowy Fundusz Zdrowia (2020b). Pobrane z: https://www.nfz.gov.pl/aktualnosci/ aktualnosci-centrali/uzdrowiska-zawieszaja-czasowo-swoja-dzialalnosc,7836.html (28.03.2021).

OECD (2021). Managing tourism development for sustainable and inclusive recovery. OECD Tourism Papers, 2021/01, 1-60.

Prawo.pl (2021). Pobrane z: https://www.prawo.pl/zdrowie/sanatoria-otwarte-od-11-marca-ruszaja-turnusy-uzdrowiskowe-i,506415.html (28.03.2021).

PKO Bank Polski (2021). Pobrane z: https://www.pkobp.pl/media_files/89b7e242-7c514ce4-8241-0294511f62bd.pdf (28.03.2021).

Raport o stanie Gminy Miasto Kołobrzeg za rok 2019 (2019). Pobrane z: http://eregion.wzp. pl/sites/default/files/raport_o_stanie_za_2019.pdf (28.03.2021).

Rathore, G.S., Dwivedi, H. (2021). Impact of Covid-19 and world's tourism industry, adidi publication. India: Raipur (Chhattisgarh).

Rynek dóbr luksusowych w Polsce (2021). Pobrane z: https://home.kpmg/pl/pl/home/ campaigns/2021/03/raport-rynek-dobr-luksusowych-w-polsce-edycja-11.html (29.03.2021).

Rynek pierwotny (2020). Pobrane z: https://rynekpierwotny.pl/wiadomosci-mieszkaniowe/ ranking-warunkow-mieszkaniowych-2019/11724/ (29.03.2021).

Skare, M., Soriano, D.R., Porada-Rochoń, M. (2021). Impact of COVID-19 on the travel and tourism industry. Technological Forecasting $\mathcal{E}$ Social Change, 163, 120469. https://doi. org/10.1016/j.techfore.2020.120469

Stowarzyszenie Gmin Uzdrowiskowych RP (2020). Pobrane z: https://sgurp.pl/aktualnosci/nowosci-z-sgu-rp/komunikat-pap-w-sprawie-narodowego-programu-wsparcia-polskich-uzdrowisk.html (27.03.2021).

Urząd Miasta Kołobrzeg (2021). Pobrane z: https://i-kolobrzeg.pl/ (27.03.2021).

Urząd Statystyczny w Szczecinie (2021). Pobrane z: https://szczecin.stat.gov.pl/ (27.03.2021).

Ustawa z dnia 28 lipca 2005 r. o lecznictwie uzdrowiskowym, uzdrowiskach i obszarach ochrony uzdrowiskowej oraz gminach uzdrowiskowych. DzU 2005, nr 167, poz. 1399.

Walas, B., Kruczek, Z. (2020). The impact of COVID-19 on tourism in Kraków in the eyes of tourism entrepreneurs. Studia Periegetica, 2 (30), 79-95. https://doi. org/10.5604/01.3001.0014.3664

Wiskulski T. (2020). COVID-19 and tourism - the case of Poland. Prace Komisji Geografii Komunikacji PTG, 23 (2), 35-39. https://doi.org/10.4467/2543859XPKG.20.005.12103

Wojewódzki Urząd Pracy w Szczecinie (2021). Pobrane z: https://www.wup.pl/ (27.03.2021). 


\title{
MIASTO-KURORT KOŁOBRZEG PO PIERWSZYM ROKU PANDEMII COVID-19
}

\begin{abstract}
Abstrakt: Celem pracy jest podjęcie próby ustalenia, jaki wpływ na funkcjonowanie miasta Kołobrzeg miała pandemia COVID-19 w aspekcie cyklicznego zamykania i otwierania obiektów lecznictwa uzdrowiskowego i bazy noclegowej największego polskiego uzdrowiska. Spośród wszystkich polskich uzdrowisk miasto Kołobrzeg reprezentuje obszar największej w skali kraju koncentracji turystycznej bazy noclegowej, liczącej według danych GUS za 2019 r. 35363 miejsc. Miasto jest bardzo atrakcyjnym miejscem lokalizacji licznych inwestycji mieszkaniowych, apartamentowych i hotelowych. Największy kurort nadmorski silnie uzależniony od turystyki i funkcji uzdrowiskowych przez ostatni rok zmagał się ze zmianami funkcjonowania bazy noclegowej, znaczącym spadkiem dochodów budżetowych, wzrostem bezrobocia, a jednocześnie dalszą intensyfikacją inwestycji mieszkaniowych, apartamentowych i hotelowych. Przebieg tych procesów od lutego 2020 r. do marca 2021 r. stanowi interesujące studium przypadku, pokazujące, jak duże kurorty nadmorskie o wiodącej funkcji uzdrowiskowej funkcjonowały w okresie pandemii COVID-19.
\end{abstract}

Słowa kluczowe: Kołobrzeg, uzdrowisko, funkcje turystyczno-uzdrowiskowe, ruch turystyczny, inwestycje, rozwój społeczno-gospodarczy.

\section{KOŁOBRZEG AS A CITY AND HEALTH RESORT AFTER THE FIRST YEAR OF THE COVID-19 PANDEMIC}

\begin{abstract}
The aim of the author was to try to determine the impact of the Covid-19 pandemic on the functioning of the city of Kołobrzeg in terms of the closings and openings of spa treatment and accommodation facilities in the largest Polish spa. Of all Polish health resorts, the city of Kołobrzeg has the largest concentration of tourist accommodation facilities in the country, officially, according to 'Statistics Poland' data for 2019, there are 35,363 places in a very attractive location with numerous residential, apartment and hotel investments. As the largest seaside resort, strongly dependent on its tourism and spa functions, it has over the last year struggled with various changes: the functioning of the accommodation base, a significant decrease in budget revenues, an increase in unemployment and at the same time a further intensification of housing, apartment and hotel investments. The course of these processes from February 2020 to March 2021 is an interesting case study showing how large seaside resorts with a leading spa function operated during the Covid-19 pandemic.
\end{abstract}

Keywords: Kołobrzeg, health resort, tourist and spa functions, level of tourism, investments, socio-economic development. 